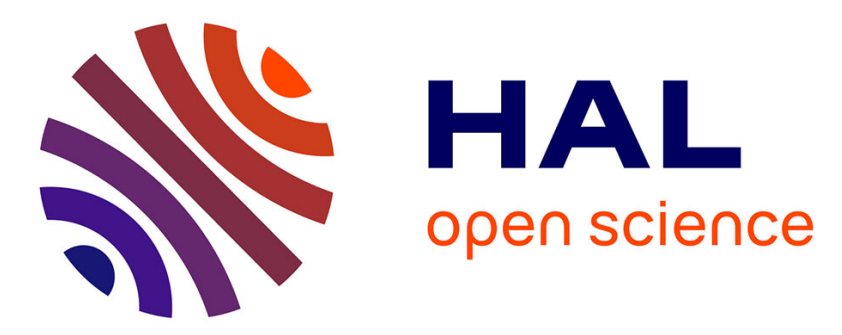

\title{
Interdependent Iron and Phosphorus Availability Controls Photosynthesis Through Retrograde Signaling
}

Hatem Rouached, Hye-In Nam, Zaigham Shahzad, Yanniv Dorone, Sophie Clowez, Kangmei Zhao, Nadia Bouain, Huikyong Cho, Seung y Rhee

\section{- To cite this version:}

Hatem Rouached, Hye-In Nam, Zaigham Shahzad, Yanniv Dorone, Sophie Clowez, et al.. Interdependent Iron and Phosphorus Availability Controls Photosynthesis Through Retrograde Signaling. 2021. hal-03153603

\section{HAL Id: hal-03153603 \\ https: / hal.inrae.fr/hal-03153603}

Preprint submitted on 26 Feb 2021

HAL is a multi-disciplinary open access archive for the deposit and dissemination of scientific research documents, whether they are published or not. The documents may come from teaching and research institutions in France or abroad, or from public or private research centers.
L'archive ouverte pluridisciplinaire HAL, est destinée au dépôt et à la diffusion de documents scientifiques de niveau recherche, publiés ou non, émanant des établissements d'enseignement et de recherche français ou étrangers, des laboratoires publics ou privés. 
1 Interdependent Iron and Phosphorus Availability Controls Photosynthesis

2 Through Retrograde Signaling

3

4 Hye-In Nam, Zaigham Shahzad ${ }^{2}$, Yanniv Dorone ${ }^{1,4}$, Sophie Clowez ${ }^{1}$, Kangmei Zhao $^{1}$, Nadia Bouain ${ }^{3}$, Huikyong $\mathrm{Cho}^{3}$, Seung Y. Rhee ${ }^{1^{*}}$, Hatem Rouached ${ }^{3,5,6^{*}}$

\author{
Affiliations: \\ ${ }^{1}$ Department of Plant Biology, Carnegie Institution for Science, Stanford, California, \\ USA \\ ${ }^{2}$ Department of Cell and Developmental Biology, John Innes Centre, Norwich NR4 \\ 7UH, UK \\ ${ }^{3}$ BPMP, Univ Montpellier, CNRS, INRAE, Montpellier SupAgro, Montpellier, France \\ ${ }^{4}$ Department of Biology, Stanford University, Stanford, CA 94305, USA \\ ${ }^{5}$ Plant Resilience Institute, Michigan State University, East Lansing, MI 48824, USA \\ ${ }^{6}$ Department of Plant, Soil, and Microbial Sciences, Michigan State University, East \\ Lansing, MI 48824, USA \\ *For correspondence: rouached@msu.edu; srhee@carnegiescience.edu
}

Iron deficiency hampers photosynthesis and is associated with chlorosis. We recently showed that iron deficiency-induced chlorosis depends on phosphorus availability. How plants integrate these cues to control chlorophyll accumulation is unknown. Here, we show that iron limitation downregulates photosynthesis genes in a phosphorus-dependent manner. Using transcriptomics and genome-wide association analysis, we identify two genes, a chloroplastic ascorbate transporter $(P H T 4 ; 4)$ and a nuclear transcription factor (bZIP58), which prevent the downregulation of photosynthesis genes leading to the stay-green phenotype under iron-phosphorus deficiency. Joint limitation of these nutrients induces ascorbate accumulation by activating expression of an ascorbate biosynthesis gene, VTC4, which requires bZIP58. Exogenous ascorbate prevents iron deficiency-induced chlorosis in vtc4 mutants, but not in bzip58 or pht4;4. Our study demonstrates chloroplastic ascorbate transport is essential for preventing the downregulation of photosynthesis genes under iron-phosphorus combined deficiency. These findings uncover a molecular pathway coordinating chloroplast-nucleus communication to adapt photosynthesis to nutrient availability. 
Chloroplasts are sites of photosynthesis, whose function requires numerous proteins encoded in the nuclear genome ${ }^{1}$. Although plants tightly orchestrate chloroplast-tonucleus signaling (retrograde control), it is poorly understood at the mechanistic level. Additionally, the adequate accumulation of nutrients such as iron (Fe) in chloroplasts is required for their optimal performance ${ }^{2,3}$. Up to $80 \%$ of Fe in leaves is located in the chloroplasts ${ }^{4,5}$, where its ability to donate and accept electrons plays a central role in electron transfer reactions ${ }^{6}$. Fe is found in all electron transfer complexes PSI, PSII, cytochrome b6f complex, and ferredoxins and is required for the biogenesis of cofactors such as hemes and iron-sulfur clusters ${ }^{7,8}$. Plants grown under Fe-deficient (-Fe) environments show chlorotic symptoms ${ }^{9}$, and compromised photosynthesis ${ }^{2,3}$. However, chlorotic leaves can also develop under highphosphorus $(P)$ conditions, despite replete $\mathrm{Fe}$ levels ${ }^{10}$, challenging the causal connection between Fe concentration and chlorophyll accumulation. Moreover, we recently reported that rice plants grown under a combined $\mathrm{Fe}$ and $\mathrm{P}$ deficiency (-FeP) do not exhibit a chlorotic phenotype ${ }^{11}$. These observations revealed a gap in our understanding of the interdependent effects of nutrient availability on regulating photosynthesis. Here, we addressed this issue through a combination of global gene expression analyses and genome-wide association studies (GWAS) to find expression quantitative trait loci (eQTLs) and uncovered a regulatory module that controls chlorophyll accumulation in response to $\mathrm{Fe}$ and $\mathrm{P}$ availability. This module involves an ascorbic acid (AsA) synthesis enzyme named VITAMINC4 (VTC4), a chloroplastic AsA transporter named PHOSPHATE TRANSPORTER 4;4 (PHT4;4), and a putative transcription factor named BASIC LEUCINE-ZIPPER 58 (bZIP58). The functioning of this module sheds light on the importance of chloroplast-nucleus communications under co-occurring nutrient deficiencies in controlling photosynthesis.

We previously reported that $\mathrm{Fe}$ deficiency-induced chlorosis depends on $\mathrm{P}$ availability in rice ${ }^{11}$. To investigate whether the interdependent effects of $\mathrm{Fe}$ and $P$ availability on chlorosis are conserved across monocot and eudicot species, we phenotyped Arabidopsis thaliana Col-0 (eudicot) and Lemna gibba (monocot), along with Oryza sativa (monocot), under different regimes of $\mathrm{Fe}$ and $\mathrm{P}$ availability. $\mathrm{Fe}$ deficiency $(-\mathrm{Fe})$ caused chlorosis in all three species, but only in the presence of $P$ ($\mathrm{Fe}+\mathrm{P}$ ) (Figure $1 \mathrm{~A}-\mathrm{C})$. Quantification of chlorophyll content confirmed that $-\mathrm{Fe}$ 
significantly reduced the accumulation of chlorophyll in all three species (Figure 1D). However, under -Fe-P conditions, chlorophyll content was comparable to control $(+\mathrm{Fe}+\mathrm{P})$ conditions in these species (Figure 1D). Next, we focused on Arabidopsis to gain insights into the physiological and molecular processes underlying the recovery of chlorosis under -Fe-P conditions. First, we asked whether absence of chlorosis under $-\mathrm{Fe}-\mathrm{P}$ is caused by an increase of $\mathrm{Fe}$ levels in shoots. Plants grown in $-\mathrm{Fe}+\mathrm{P}$ conditions decreased total $\mathrm{Fe}$ in shoots by 2-fold compared to $+\mathrm{Fe}+\mathrm{P}$ conditions (Figure 1E). On the other hand, under +Fe-P conditions, Fe levels increased by 2.2fold relative to $+\mathrm{Fe}+\mathrm{P}$ conditions (Figure 1E). Surprisingly, Fe levels in plants grown under -Fe-P were reduced and indistinguishable from the $\mathrm{Fe}$ levels in $-\mathrm{Fe}+\mathrm{P}$ conditions (Figure 1E). Therefore, the lack of chlorosis under -Fe-P is unlikely to be caused by more Fe available in shoots. To further test this hypothesis, we assessed free $\mathrm{Fe}$ in leaves. Because FERRITIN1 (AtFER1) chelates $\mathrm{Fe}$ and its mRNA increases when $\mathrm{Fe}$ is in access, AtFER1 gene expression can be used as a read-out for intracellular Fe nutritional status ${ }^{12}$. We thus quantified the expression of AtFER1 in shoots under replete or deficient Fe and $\mathrm{P}$ in the growth media. Consistent with the total Fe levels, AtFER1 expression was increased significantly under +Fe-P conditions relative to $+\mathrm{Fe}+\mathrm{P}$ (Figure 1F). However, AtFER1 expression decreased under both $-\mathrm{Fe}+\mathrm{P}$ and $-\mathrm{Fe}-\mathrm{P}$ conditions relative to $+\mathrm{Fe}+\mathrm{P}$ (Figure 1F). Interestingly, -Fe-P condition caused a slightly bigger reduction in AtFER1 expression than $-\mathrm{Fe}+\mathrm{P}$ did, suggesting that there may be even less free $\mathrm{Fe}$ in $-\mathrm{Fe}-\mathrm{P}$ conditions than in $-\mathrm{Fe}+\mathrm{P}$ conditions. Taken together, these data show that the onset of chlorosis during $-\mathrm{Fe}$ requires sufficient $P$ in the growth media, and that the "stay green" phenotype under the combined -Fe-P deficiency cannot be linked to Fe nutritional status in leaves.

To understand the cause of chlorophyll reduction in response to -Fe, we first explored the timing of -Fe sensing and photosynthetic function response. Since $-\mathrm{Fe}$ affects chlorophyll accumulation and photosystem II (PSII) activity ${ }^{13,14}$, we monitored their kinetics over 172 hours (h) (Figure 2A-B, Figure S1A-C). Arabidopsis plants were first grown on $+\mathrm{Fe}+\mathrm{P}$ media for one week, and then transferred to $+\mathrm{Fe}+\mathrm{P}$, $102 \mathrm{Fe}+\mathrm{P}$, or $-\mathrm{Fe}-\mathrm{P}$ conditions. $-\mathrm{Fe}+\mathrm{P}$ caused a significant decrease in chlorophyll content observable starting at $52 \mathrm{~h}$ after the transfer to $-\mathrm{Fe}+\mathrm{P}$ (Figure $2 \mathrm{~A}$ ). However,

104 transfer to -Fe-P did not affect chlorophyll content, even at $172 \mathrm{~h}$ after the transfer 105 (Figure 2A). To determine how photosynthesis was affected, we measured Fv/Fm, 
106 which reflects the quantum yield of photochemistry and is a measure of PSII 107 activity ${ }^{13,14}$. Plants under $-\mathrm{Fe}+\mathrm{P}$ decreased Fv/Fm observable starting at 52h, 108 indicative of compromised electron transport through PSII, and which coincides with 109 the decrease of chlorophyll accumulation (Figure 2B). By 172 h, PSIl activity was 110 substantially reduced under $-\mathrm{Fe}+\mathrm{P}$ compared to $+\mathrm{Fe}+\mathrm{P}$. However, plants under $-\mathrm{Fe}-\mathrm{P}$ 111 showed slightly lower but stabilized Fv/Fm compared to those in +Fe+P (Figure 2B). 112 These physiological characterizations showed that chlorophyll accumulation and PSII 113 activity were affected by $-\mathrm{Fe}$, and both responses were P-dependent (Figure 2A-B).

115 Based on these findings, we selected three time points at 39, 52, and $76 \mathrm{~h}$ after the 116 transfer of plants to $+\mathrm{Fe}+\mathrm{P}$, $-\mathrm{Fe}+\mathrm{P}$, or $-\mathrm{Fe}-\mathrm{P}$ to conduct a global gene expression 117 analysis in shoots (Figure 2C, Figure S2A-F). We identified genes whose expression 118 levels were either increased or decreased by $-\mathrm{Fe}+\mathrm{P}$ relative to $+\mathrm{Fe}+\mathrm{P}$ by at least 2119 fold at a p-value < 0.05 (Figures 2D, Table S1). Even more genes were either 120 upregulated or downregulated in $-\mathrm{Fe}-\mathrm{P}$ conditions relative to $+\mathrm{Fe}+\mathrm{P}$ (Figures 2D, 121 Figure S3A-C). A total of 671 and 2434 transcripts were uniquely differentially 122 regulated in response to $-\mathrm{Fe}+\mathrm{P}$ or $-\mathrm{Fe}-\mathrm{P}$, respectively, supporting the existence of 123 different signaling pathways under the two conditions (Figure S 3A-C). To identify 124 functions enriched in genes that were differently regulated by $-\mathrm{Fe}+\mathrm{P}$ or $-\mathrm{Fe}-\mathrm{P}$, we 125 performed Gene Ontology (GO) enrichment analysis. Genes specifically 126 downregulated by $-\mathrm{Fe}-\mathrm{P}$ but not by $-\mathrm{Fe}+\mathrm{P}$ at $52 \mathrm{~h}$ and $76 \mathrm{~h}$ (52 genes; Figure S4A, 127 Table S1) showed an enrichment for ribosomal genes (Figure S4B) while 128 upregulated genes (162 genes, Figure S4C, Table S1) revealed an enrichment for 129 genes involved in cation transport, response to water, and ester hydrolysis (Figure 130 S4D, Table S1). On the other hand, GO analysis of the 32 genes specifically 131 downregulated by $-\mathrm{Fe}+\mathrm{P}$ but not affected by $-\mathrm{Fe}-\mathrm{P}$ at $52 \mathrm{~h}$ and $76 \mathrm{~h}$ (Figure 2E, Table 132 S1) revealed an enrichment of genes related to the chloroplast and photosynthesis133 related processes (Figure 2F), while upregulated genes (Figure S4E) were enriched 134 for genes related to cellular respiration, oxidation-reduction process, and energy 135 metabolism (35 genes; Figure S4F). Altogether, the transcriptomics analysis 136 indicated that the control of chloroplast function is an integral component of the 137 nuclear transcriptomic response to $-\mathrm{Fe}$, which is dependent on $\mathrm{P}$ availability. We also 138 learned that the photosynthesis-related phenotypes we observed under $-\mathrm{Fe}+\mathrm{P}$, but 139 not under -Fe-P, could be due to downregulation of key photosynthesis regulators. 
140 To decode the signaling pathways that control expression of the photosynthesis 141 genes in response to $-\mathrm{Fe}+\mathrm{P}$, we exploited natural variation in expression of the 32 142 genes that were down-regulated by Fe deficiency in a P-dependent manner in a 143 worldwide collection of $A$. thaliana accessions ${ }^{15}$. One way to identify regulatory 144 mechanisms could be to perform expression genome-wide association studies 145 (eGWAS) using the expression level of individual genes across Arabidopsis 146 accessions. Strikingly, we found that expression levels of the 32 genes are 147 predominantly positively associated with each other across 727 Arabidopsis 148 accessions (Figure S5A) ${ }^{15}$. We then performed Principal Component Analysis (PCA) 149 to reduce the dimensionality of these expression data. PC1 explained $89.5 \%$ of the 150 variation in expression of these genes across Arabidopsis accessions (Figure S5B).

151 The contribution of each accession to PC1 was then used to perform a genome-wide 152 association study (GWAS) (Figure 3A). Our GWAS analysis detected 38 QTLs 153 containing 145 candidate genes, based on a $20-\mathrm{kb}$ window per QTL and using a 5\% 154 false discovery rate (FDR) threshold, with the highest peak (Chromosome 2) 155 occurring in an intergenic region (Figure 3A). In this study, we followed up one of the 156 QTLs that contained the inorganic phosphate transporter PHT4;4 (AT4G00370) 157 (Figure 3A, Figures S6 and S7) given its role in ascorbic acid (AsA) transport into 158 chloroplasts, which was proposed to be important for maintaining the xanthophyll 159 cycle for dissipation of excessive light energy to heat in photosynthesis ${ }^{16}$. To 160 determine if PHT4;4 has any role in -Fe+P dependent chlorosis, we examined 161 mutants with a null pht4;4 allele. Under -Fe+P, chlorophyll was significantly reduced 162 in pht4;4 mutants, similar to wild type plants (Figure 3B-C). However, -Fe-P 163 conditions failed to recover chlorosis and chlorophyll reduction in pht4;4 mutants, 164 unlike wild type plants (Figure 3B-C). Introduction of the wild type PHT4;4 allele into 165 a pht4;4 mutant background complemented these phenotypes (Figure 3B-C). The 166 chlorotic phenotype of the pht4;4 mutant under -Fe-P suggested that transport of AsA 167 into chloroplasts could be important for the "stay green" phenotype.

169 To test our hypothesis about the role of AsA in preventing chlorosis under $-\mathrm{Fe}-\mathrm{P}$ 170 conditions, we first assessed how $\mathrm{Fe}$ and $\mathrm{P}$ availabilities regulate the expression of 171 VITAMIN C (VTC) enzymes involved in AsA biosynthesis in plants ${ }^{17}$. Our RNA-seq 172 analysis identified that -Fe-P caused a 2 to 3-fold increase in VTC1, VTC2, and 173 VTC4 expression, which we confirmed using qRT-PCR (Figure 3D). However, -Fe in 
174 the presence of $\mathrm{P}(-\mathrm{Fe}+\mathrm{P})$ caused a 2-fold decrease in the mRNA abundance of 175 VTC4 (Figure 3D). VTC4 is the final enzyme in the AsA biosynthesis pathway ${ }^{17}$. This 176 prompted us to test the effect of the absence of VTC4 on chlorophyll accumulation 177 under $-\mathrm{Fe}+\mathrm{P}$ and $-\mathrm{Fe}-\mathrm{P}$ conditions. Under $-\mathrm{Fe}-\mathrm{P}$, mutants with a vtc4 null allele were 178 still chlorotic, similarly to pht4;4 and in contrast to wild type plants (Figure 3B-C).

179 These data show that AsA contributes to preventing chlorosis in -Fe-P conditions.

181 Next, we tested whether the chlorotic phenotype is due to variations in AsA levels. In wild type, AsA levels decreased significantly under $-\mathrm{Fe}+\mathrm{P}$ at $52 \mathrm{~h}$ after the transfer relative to control $(+\mathrm{Fe}+\mathrm{P})$, whereas no change was detected under $-\mathrm{Fe}-\mathrm{P}$ (Figure $3 E)$, suggesting that AsA levels were associated with -Fe-mediated chlorosis. To test whether AsA levels were associated with chlorosis in general, we measured AsA levels in AsA synthesis (vtc4) mutant plants. Under $+\mathrm{Fe}+\mathrm{P}$, vtc4 plants accumulated $35 \%$ less AsA than wild type plants, and AsA levels remained unchanged in response to $-\mathrm{Fe}+\mathrm{P}$ or $-\mathrm{Fe}-\mathrm{P}$ stress (Figure 3E). However, vtc4 plants did not show the chlorotic phenotype under $+\mathrm{Fe}+\mathrm{P}$, which indicated that the level of AsA contributed to the chlorotic phenotype specifically under -Fe and this contribution was dependent on $\mathrm{P}$ availability. In addition, the AsA transporter (pht4;4) mutants showed similar AsA levels as the wild type even though pht4;4 plants were still chlorotic in Fe-P (Figure 3E). To determine whether AsA accumulation in the cell or its transport 194 to the chloroplast is associated with the development of chlorotic phenotype in $195 \mathrm{Fe}+\mathrm{P}$, we tested the effect of an exogenous supply of AsA in wild type, vtc4, and pht4;4 plants (Figure 3B-C). Exogenous AsA alleviated the chlorosis caused by $197 \mathrm{Fe}+\mathrm{P}$ in wild type and vtc4 mutant plants. However, pht4;4 mutants failed to stay green under $-\mathrm{Fe}+\mathrm{P}+\mathrm{As} \mathrm{A}$ conditions (Figure $3 \mathrm{~B}-\mathrm{C}$ ), indicating that the transport of 199 AsA to the chloroplast is required for $-\mathrm{P}$ mediated 'stay green' phenotype under Fe 200 deficiency. Our results showed that $-\mathrm{P}$ prevents the downregulation of VTC4 by $-\mathrm{Fe}$ 201 and associated changes in AsA accumulation, and that the PHT4;4-mediated 202 transport of AsA to chloroplasts is required for the maintenance of chlorophyll content 203 under combined deficiency of Fe and $\mathrm{P}$.

205 We next asked whether PHT4;4-mediated AsA transport to the chloroplast is 206 important for regulation of the photosynthesis-related genes that were specifically 207 down-regulated by $-\mathrm{Fe}$ in a P-dependent manner. First, we tested the effects of 
208 PHT4;4 inactivation on the expression of these photosynthesis related genes using 209 qRT-PCR (Figure 4A). While -Fe+P significantly downregulated the mRNA 210 abundance of these genes in wild type plants (Col-0), -Fe-P prevented this response 211 (Figure 4A). Furthermore, adding AsA to -Fe+P mimicked -Fe-P response in 212 preventing down-regulation of the photosynthesis genes. Under $-\mathrm{Fe}+\mathrm{P}$, pht4;4 213 mutant plants showed a decrease in the mRNA abundance of these genes 214 comparable to wild type plants (Figure 4A). However, in contrast to the wild type, 215 these genes were still downregulated in pht4;4 plants under $-\mathrm{Fe}-\mathrm{P}$ as well as $-\mathrm{Fe}+\mathrm{P}$ 216 supplemented with AsA (Figure 4A). Taken together, these data indicate that the 217 transport of AsA to chloroplasts via PHT4;4 is central to preventing the 218 downregulation of photosynthesis-related genes under -Fe-P.

How does -Fe+P affect the expression of photosynthesis-related genes? To look for potential transcriptional regulators of these genes, we examined the candidate genes 222 from the GWAS analysis. We found that bZIP58 (AT1G13600) (Figure 3A, Figure S6223 S7), a putative transcription factor, underlies one of the strongest QTL peaks (Figure $2243 \mathrm{~A}$ ). To test whether bZIP58 responds to Fe and $\mathrm{P}$ availability, we performed qRT225 PCR of bZIP58 under various $\mathrm{Fe}$ and $\mathrm{P}$ availability. bZIP58 was strongly 226 downregulated by -Fe, and this down-regulation depended on $\mathrm{P}$ availability (Figure 227 4B). In addition, bZIP58 was partially required to induce VTC4 expression under -Fe$228 \mathrm{P}$ conditions (Figure $4 \mathrm{C}$ ). This led us to examine the contribution of bZIP58 in 229 regulating the $-\mathrm{Fe}+\mathrm{P}$ specific photosynthesis-related genes under $+\mathrm{Fe}+\mathrm{P},-\mathrm{Fe}+\mathrm{P}$, 230 Fe-P conditions (Figure 4A). Mutants with the bzip58 null allele showed a remarkable 231 constitutive decrease in the expression of these 32 photosynthesis-related genes 232 (Figure 4A). bZIP58 localizes to the nucleus (Figure 4D), which is consistent with a 233 role as a transcription factor. Taken together, these findings support the idea that 234 bZIP58 is a key regulator of photosynthesis-related genes, and its absence could 235 alter chlorophyll accumulation regardless of $\mathrm{Fe}$ and $\mathrm{P}$ availability. Genetic inactivation 236 of bZIP58 indeed causes a constitutive decrease in chlorophyll content, and the 237 mutant line is chlorotic (Figure 4E-F). The expression of bZIP58 gene in bzip58 238 plants complements the constitutive chlorosis phenotype, and the complemented line 239 responds to $\mathrm{Fe}$ and $\mathrm{P}$ availability similarly to wild type plants (Figure 4E-F). 240 Furthermore, AsA supplementation could not rescue the chlorotic phenotype of 241 bzip58 mutants (Figure 4E-F), indicating that pZIP58 lies downstream of AsA action. 
242 These data show that bZIP58 controls the expression of photosynthesis-related

243 genes and is transcriptionally regulated in response to -Fe depending on $\mathrm{P}$

244 availability, likely by mediating the perception of AsA.

246 Based on our findings, we propose a model to explain how $\mathrm{P}$ availability modulates 247 Fe deficiency-induced chlorosis (Figure 4G). -Fe+P causes a decrease in the 248 expression of AsA biosynthesis gene VTC4 (Figure 3D). Exogenous AsA supply 249 prevents the development of chlorosis in vtc4 under -Fe-P, but not in the pht4;4 that 250 transports AsA to the chloroplast (Figure 3B). We thus propose that AsA deficiency in 251 the chloroplast under Fe limited conditions triggers chlorosis. How does AsA in the 252 chloroplast affect photosynthesis? AsA has an antioxidizing action that detoxifies 253 reactive oxygen species (ROS) through its scavenging properties ${ }^{18}$, thus making 254 ROS a potential signaling molecule ${ }^{19-21}$ capable of modulating the expression of 255 photosynthesis-related genes through bZIP58. To test this hypothesis, we measured 256 the relative amount of ROS accumulation in shoots of wild type, pht4;4 and bzip58 plants under various $\mathrm{Fe}$ and $\mathrm{P}$ availability. $-\mathrm{Fe}+\mathrm{P}$ caused a 2-fold increase in ROS accumulation in shoots of wild type plants, which partially depended on $\mathrm{P}$ availability

259 (Figure 4H). pht4;4 plants displayed comparable ROS accumulation to that of the 260 wild type under $+\mathrm{Fe}+\mathrm{P}$ and $-\mathrm{Fe}+\mathrm{P}$. However, pht4;4 plants accumulated significantly 261 higher ROS than wild type plants under -Fe-P (Figure 4H). In addition, bzip58 mutant 262 plants displayed a constitutive increase in ROS accumulation (Figure 4H). To check 263 whether ROS in turn can regulate the expression of bZIP58, we quantified bZIP58 264 expression in response to foliar application of $\mathrm{H}_{2} \mathrm{O}_{2}$. ROS treatment caused a 4-fold decrease in bZIP58 transcript accumulation (Figure 4B). Collectively, our results support the idea that under simultaneous Fe and $P$ deficiency, AsA accumulation in the chloroplast prevents chlorosis by modulating ROS levels that may control the expression of photosynthesis genes via a putative transcription factor bZIP58 (Figure $4 G)$. How ROS acts as a retrograde signal to alter nuclear gene expression to control photosynthesis under Fe and $\mathrm{P}$ limitation remains to be determined, though we now have several molecular targets with which to explore this field. Modulation of the discovered pathway could have a direct impact on plant growth in the field by

273 improving plant photosynthetic activity while reducing nutrient supply.

\section{References}


2761 Myouga, F. et al. The Chloroplast Function Database: a large - scale

277 collection of Arabidopsis Ds/Spm - or T - DNA - tagged homozygous lines for nuclear - encoded chloroplast proteins, and their systematic phenotype analysis. Plant J. 61, 529-542 (2010).

2 Chen, Y. \& Barak, P. Iron nutrition of plants in calcareous soils. Adv. Agron. 35, 217-240 (1982).

3 Carstensen, A. et al. The impacts of phosphorus deficiency on the photosynthetic electron transport chain. Plant Physiol. 177, 271-284 (2018).

4 Terry, N. \& Abadía, J. Function of iron in chloroplasts. J. Plant Nutr. 9, 609646 (1986).

5 Terry, N. \& Low, G. Leaf chlorophyll content and its relation to the intracellular localization of iron. J. Plant Nutr. 5, 301-310 (1982).

$6 \quad$ Lill, R. Function and biogenesis of iron-sulphur proteins. Nature 460, 831 (2009).

7 Briat, J.-F., Dubos, C. \& Gaymard, F. Iron nutrition, biomass production, and plant product quality. Trends Plant Sci. 20, 33-40 (2015).

8 Balk, J. \& Pilon, M. Ancient and essential: the assembly of iron-sulfur clusters in plants. Trends Plant Sci. 16, 218-226 (2011).

9 Marschner, H. Mineral nutrition of higher plants. 2nd. (Academic Press, Elsevier, 1995).

10 DeKock, P. C., Hall, A. \& Inkson, R. H. E. Active iron in plant leaves. Ann. Bot. 43, 737-740 (1979).

11 Saenchai, C. et al. The involvement of OsPHO1; 1 in the regulation of iron transport through integration of phosphate and zinc deficiency signaling. Front. Plant Sci. 7, 396 (2016).

12 Bournier, M. et al. Arabidopsis ferritin 1 (AtFer1) gene regulation by the phosphate starvation response 1 (AtPHR1) transcription factor reveals a direct molecular link between iron and phosphate homeostasis. J. Biol. Chem. 288, 22670-22680 (2013).

13 Bertamini, M., Nedunchezhian, N. \& Borghi, B. Effect of iron deficiency induced changes on photosynthetic pigments, ribulose-1, 5-bisphosphate carboxylase, and photosystem activities in field grown grapevine (Vitis vinifera L. cv. Pinot noir) leaves. Photosynthetica 39, 59-65 (2001).

14 Liu, W. et al. The ethylene response factor AtERF4 negatively regulates the iron deficiency response in Arabidopsis thaliana. PLoS ONE 12, e0186580 (2017).

15 Kawakatsu, T. et al. Epigenomic diversity in a global collection of Arabidopsis thaliana accessions. Cell 166, 492-505 (2016).

16 Miyaji, T. et al. AtPHT4; 4 is a chloroplast-localized ascorbate transporter in Arabidopsis. Nat. Commun. 6, 5928 (2015).

17 Torabinejad, J., Donahue, J. L., Gunesekera, B. N., Allen-Daniels, M. J. \& Gillaspy, G. E. VTC4 is a bifunctional enzyme that affects myoinositol and ascorbate biosynthesis in plants. Plant Physiol. 150, 951-961 (2009).

18 Noctor, G. \& Foyer, C. H. Ascorbate and glutathione: keeping active oxygen under control. Annu. Rev. Plant Biol. 49, 249-279 (1998).

19 Finkel, T. Signal transduction by reactive oxygen species. J. Cell Biol. 194, 715 (2011).

20 Shapiguzov, A., Vainonen, J., Wrzaczek, M. \& Kangasjärvi, J. ROS-talk-how the apoplast, the chloroplast, and the nucleus get the message through. Front. Plant Sci. 3, 292 (2012). 
21 Shaikhali, J. \& Wingsle, G. Redox-regulated transcription in plants: emerging concepts. AIMS Mol. Sci. 4, 301 (2017).

22 Warde-Farley, D. et al. The GeneMANIA prediction server: biological network integration for gene prioritization and predicting gene function. Nucleic Acids Res. 38, W214-W220 (2010).

23 Haydon, M. J. et al. Vacuolar nicotianamine has critical and distinct roles under iron deficiency and for zinc sequestration in Arabidopsis. Plant Cell 24, 724-737 (2012). studies of rice. (International Rice Research Institute, 1976).

25 Baker, N. R. Chlorophyll fluorescence: a probe of photosynthesis in vivo. Annu. Rev. Plant Biol. 59, 89-113 (2008).

26 Zhang, J., Han, C. \& Liu, Z. Absorption spectrum estimating rice chlorophyll concentration: preliminary investigations. J. Plant Breed. Crop Sci. 1, 223-229 (2009).

27 Gillespie, K. M. \& Ainsworth, E. A. Measurement of reduced, oxidized and total ascorbate content in plants. Nat. Protoc. 2, 871-874 (2007).

28 Alexieva, V., Sergiev, I., Mapelli, S. \& Karanov, E. The effect of drought and ultraviolet radiation on growth and stress markers in pea and wheat. Plant Cell Environ. 24, 1337-1344 (2001).

29 Gechev, T., Mehterov, N., Denev, I. \& Hille, J. A simple and powerful approach for isolation of Arabidopsis mutants with increased tolerance to H2O2-induced cell death. Methods Enzymol. 527, 203-220 (2013).

30 Kim, D., Langmead, B. \& Salzberg, S. L. HISAT: a fast spliced aligner with low memory requirements. Nat. Methods 12, 357-360 (2015).

31 Afgan, E. et al. The Galaxy platform for accessible, reproducible and collaborative biomedical analyses: 2018 update. Nucleic Acids Res. 46, W537-W544 (2018).

32 Love, M. I., Huber, W. \& Anders, S. Moderated estimation of fold change and dispersion for RNA-seq data with DESeq2. Genome Biol. 15, 550 (2014).

33 Rouached, $\mathrm{H}$. et al. Differential regulation of the expression of two high-affinity sulfate transporters, SULTR1. 1 and SULTR1. 2, in Arabidopsis. Plant Physiol. 147, 897-911 (2008).

34 Consortium, O. T. O. G. 1,135 genomes reveal the global pattern of polymorphism in Arabidopsis thaliana. Cell 166, 481-491 (2016).

35 Seren, Ü. et al. GWAPP: a web application for genome-wide association mapping in Arabidopsis. Plant Cell 24, 4793-4805 (2012).

36 Benjamini, Y. \& Hochberg, Y. Controlling the false discovery rate: a practical and powerful approach to multiple testing. J. R. Stat. Soc. 57, 289-300 (1995).

37 Spitzer, M., Wildenhain, J., Rappsilber, J. \& Tyers, M. BoxPlotR: a web tool for generation of box plots. Nat. Methods 11, 121 (2014).

\section{Figure Legends}

370 evolutionarily distant plant species. A-C) Duckweed (Lemna gibba), rice (Oryza

371 sativa cv Nipponbare), and Arabidopsis thaliana plants grown on media containing 372 iron and phosphorus $(+\mathrm{Fe}+\mathrm{P})$, deficient in iron $(-\mathrm{Fe}+\mathrm{P})$, or deficient in both elements 
373 (-Fe-P). Representative images of L. gibba propagated for 28 days (A), 24-day old 374 rice (B) and 14-day old $A$. thaliana (Col-0) (C) are shown. D) Chlorophyll 375 accumulation in L. gibba, $A$. thaliana, and $O$. sativa grown under $+\mathrm{Fe}+\mathrm{P},-\mathrm{Fe}+\mathrm{P}$, and 376 Fe-P conditions. Scale bars, $7 \mathrm{~mm}(\mathrm{~A}), 10 \mathrm{~mm}(\mathrm{~B})$, and $5 \mathrm{~mm}(\mathrm{C})$. Data shown are 377 from 3 experiments and 3-10 plants per experiment. Error bars represent 95\% 378 confidence interval. FW, fresh weight. E) Iron content in shoots of $A$. thaliana plants 379 grown on agar plates containing $+\mathrm{Fe}+\mathrm{P},-\mathrm{Fe}+\mathrm{P}$, or $-\mathrm{Fe}-\mathrm{P}$. Data shown are from 3 380 experiments and 10 plants per experiment. Error bars represent $95 \%$ confidence 381 interval. DW, dry weight. F) mRNA abundance of FERRITIN1 (AtFER1) relative to 382 Ubiquitin 10 (At4g05320) in A. thaliana shoots grown under $+\mathrm{Fe}+\mathrm{P},-\mathrm{Fe}+\mathrm{P}$, or $-\mathrm{Fe}-\mathrm{P}$. 383 Data shown from 3 experiments, with above-ground tissue from 5 plants pooled per experiment for RNA extraction. Error bars represent 95\% confidence interval. For D$\mathrm{F}$, letters above bars represent statistically different means at $\mathrm{P}<0.05$ (one-way ANOVA with a Duncan post-hoc test). Source data are provided as a Source Data file.

Figure 2. Kinetics of chlorophyll accumulation, photosystem II activity, and transcriptome change in response to iron and phosphorus availability. A-B) Chlorophyll content and PSII activity (Fv/Fm) in response to iron and/or phosphate deficiency in $A$. thaliana. Seedlings were grown for 7 days in the presence of iron and phosphorus $(+\mathrm{Fe}+\mathrm{P})$ and transferred to three different media: $+\mathrm{Fe}+\mathrm{P},-\mathrm{Fe}+\mathrm{P}$, or $-\mathrm{Fe}-$ P for 15h, 28h, 39h, 52h, 76h, 100h, 124h, 148h, 172h. A) Chlorophyll data shown are from 3 experiments, each experiment with 8 plants. Error bars represent 95\% confidence interval. B) Plants were dark-adapted for $30 \mathrm{~min}$ before measuring fluorescence kinetics from a leaf. Fv/Fm data shown are from 3 experiments, each experiment with 16 plants. Error bars represent 95\% confidence interval. C)

399 Experimental design for transcriptomic studies on $A$. thaliana (Col-0) shoots. Plants 400 were grown in media containing iron and phosphorus $(+\mathrm{Fe}+\mathrm{P})$ for 7 days, transferred 401 to three different media $(+\mathrm{Fe}+\mathrm{P},-\mathrm{Fe}+\mathrm{P}$, or $-\mathrm{Fe}-\mathrm{P})$ for $39 \mathrm{~h}, 52 \mathrm{~h}$, or $76 \mathrm{~h}$, and shoots were harvested for RNA extraction and sequencing. D) Global expression analysis of genes in response to $-\mathrm{Fe}+\mathrm{P}$ and $-\mathrm{Fe}-\mathrm{P}$ relative to $+\mathrm{Fe}+\mathrm{P}$. Numbers of genes 404 displaying at least 2 -fold change $(p$-value $<0.05)$ in their expression are shown for 
each condition. The 32 genes that were decreased specifically in -Fe+P but not in -

Fe- $\mathrm{P}$ relative to $+\mathrm{Fe}+\mathrm{P}$ at $52 \mathrm{~h}$ and $76 \mathrm{~h}$ (highlighted in purple) were used to perform genome-wide association studies. E) A heatmap showing gene expression patterns of the 32 genes in $-\mathrm{Fe}+\mathrm{P}$ and $-\mathrm{Fe}-\mathrm{P}$ relative to control $(+\mathrm{Fe}+\mathrm{P})$ at $39 \mathrm{~h}, 52 \mathrm{~h}, 76 \mathrm{~h}$ after the transfer. LogFC, log2 fold change. F) Gene Ontology analysis for the biological processes (GO-BP) for the 32 genes whose mRNA abundance was specifically decreased by $-\mathrm{Fe}+\mathrm{P}$. FDR $=$ false discovery rate. Source data are provided as a

412 Source Data file.

Figure 3. PHT4;4 prevents chlorosis under the combined deficiency of iron and

phosphorus. A) A Manhattan plot for genome-wide association mapping using principal component 1 that explained $89.5 \%$ of expression variation of the 32 photosynthesis related genes across $727 A$. thaliana accessions ${ }^{15}$. The five chromosomes are depicted by light and dark blue colors. Dashed lines correspond to FDR 5\% threshold (blue) and Bonferroni $\alpha=0.05$ (red). The light grey rectangle highlights a significant association located in an intergenic region (SNP: 4493712). Two significant associations that were followed up in this study are highlighted in red rectangles. B) Representative images of wild-type Col-0, pht4;4, vtc4, and a line expressing genomic PHT4;4 in pht4;4 (pht4;4-CL) grown for 7 days in the presence of iron and phosphorus $(+\mathrm{Fe}+\mathrm{P})$ and transferred to three different media: $+\mathrm{Fe}+\mathrm{P}$, $\mathrm{Fe}+\mathrm{P}$, or $-\mathrm{Fe}-\mathrm{P}$ for 7 additional days. Scale bars: $7 \mathrm{~mm} \mathrm{C}$ ) Total chlorophyll content in Col-0, pht4;4, vtc4, and PHT4;4-CL grown under -Fe+P, +Fe-P, -Fe-P, or $427 \mathrm{Fe}+\mathrm{P}+\mathrm{AsA}$. Data shown are from 10 plants conducted in three independent experiments. D) mRNA abundance of VTC genes (VTC1, VTC2, and VTC4) relative to Ubiquitin 10 (At4g05320) in shoots of $A$. thaliana Col-0 plants grown in the presence of iron and phosphorus $(+\mathrm{Fe}+\mathrm{P})$ for 7 days and transferred to $+\mathrm{Fe}+\mathrm{P}$, $\mathrm{Fe}+\mathrm{P},-\mathrm{Fe}-\mathrm{P}$ or $-\mathrm{Fe}-\mathrm{P}+\mathrm{AsA}$ for 52h. Data shown are from 3 experiments. Error bars represent 95\% confidence interval. E) Total ascorbic acid (AsA) content in Col-0, 434 phosphorus $(+\mathrm{Fe}+\mathrm{P})$ and transferred to $+\mathrm{Fe}+\mathrm{P},-\mathrm{Fe}+\mathrm{P}$, or $-\mathrm{Fe}-\mathrm{P}$ for $52 \mathrm{~h}$. Data shown are from 3 experiments, each with 16 plants. In box plots $(C, E)$ center lines show sample medians; box limits indicate the 25th and 75th percentiles; whiskers extend 
1.5 times the interquartile range from the 25th and 75th percentiles. For C-E, letters

above bars or boxes represent statistically different means at $P<0.05$ (one-way ANOVA with a Duncan post-hoc test). Data points are plotted as open circles. Source data are provided as a Source Data file.

Figure 4. bZIP58 regulates photosynthesis related genes and chlorophyll accumulation. A) mRNA abundance of 32 photosynthesis-related genes relative to Ubiquitin 10 in shoots of $A$. thaliana Col-0, pht4;4, and bzip58 plants grown for 7 days in the presence of iron and phosphorus $(+\mathrm{Fe}+\mathrm{P})$ and transferred to $+\mathrm{Fe}+\mathrm{P},-\mathrm{Fe}+\mathrm{P}$, $446 \mathrm{Fe}-\mathrm{P}$, or $-\mathrm{Fe}-\mathrm{P}+\mathrm{AsA}$ for 52h. Data were averaged from three independent experiments. Scale bar represents the relative mRNA abundance. B) mRNA abundance of bZIP58 relative to Ubiquitin 10 in $A$. thaliana Col-0 shoots of plants grown for 7 days on $+\mathrm{Fe}+\mathrm{P}$ and transferred to $+\mathrm{Fe}+\mathrm{P},-\mathrm{Fe}+\mathrm{P},-\mathrm{Fe}-\mathrm{P}$, or $+\mathrm{Fe}+\mathrm{P}+\mathrm{H}_{2} \mathrm{O}_{2}$ for 52h. Data are shown from 3 experiments. Error bars represent $95 \%$ confidence interval. C) VTC4 mRNA abundance relative to Ubiquitin 10 in the shoots of Col-0 and bzip58 mutants grown in the presence of $+\mathrm{Fe}+\mathrm{P}$ for 7 days and transferred to $+\mathrm{Fe}+\mathrm{P}$, $-\mathrm{Fe}+\mathrm{P}$, or $-\mathrm{Fe}-\mathrm{P}$ for 52h. Data shown from 3 experiments. Error bars represent $95 \%$ confidence interval.

D) Confocal microscopy images of p35S::bZIP58::GFP expressing plants (scale bar $=20 \mu \mathrm{m}$ ) grown for 7 days under $+\mathrm{Fe}+\mathrm{P}$. E) Representative images of Col-0, bzip58, and a line expressing genomic bZIP58 in bzip58 mutants (bzip58-CL) grown for 7 days in +Fe+P and transferred to $+\mathrm{Fe}+\mathrm{P}$, $-\mathrm{Fe}+\mathrm{P}$, or $-\mathrm{Fe}-\mathrm{P}$ for 7 additional days. Scale bars: $7 \mathrm{~mm}$. F) Total chlorophyll content in Col-0, bzip58, and bZIP58-CL plants grown for 7 days in $+\mathrm{Fe}+\mathrm{P}$ and transferred to $-\mathrm{Fe}+\mathrm{P},+\mathrm{Fe}-\mathrm{P}$, $-\mathrm{Fe}-\mathrm{P}$, or $-\mathrm{Fe}-\mathrm{P}+\mathrm{AsA}$ for 7 days. Data shown are from 4 experiments. G) A schematic model delineating a signaling pathway that integrates

462 Fe and $\mathrm{P}$ availability cues to regulate chlorophyll accumulation and photosynthesis genes. Fe deficiency $(-\mathrm{Fe}+\mathrm{P})$ causes a decrease in the expression of $b Z I P 58$ that is central to controlling the transcription of nuclear-encoded photosynthetic genes. $\mathrm{P}$ 465 limitation under Fe deficiency (-Fe-P) prevents this downregulation of bZIP58 and induces VTC4. The induction of VTC4 expression requires bZIP58, whose effect could be direct or indirect, represented here by ' $X$ '. We propose that induction of VTC4 increases ascorbic acid in the chloroplast mediated

by $\mathrm{PHT} 4 ; 4$. We 
hypothesize that the increase of ascorbic acid level prevents ROS accumulation, thus maintaining the expression of bZIP58 and its downstream photosynthesis genes

471 leading to the 'stay green' phenotype. $\mathbf{H}$ ) Accumulation of $\mathrm{H}_{2} \mathrm{O}_{2}$ (a type of ROS) in 472 shoots of Col-0, bzip58, and bZIP58-CL plants grown for 7 days in $+\mathrm{Fe}+\mathrm{P}$ and 473 transferred to $+\mathrm{Fe}+\mathrm{P}$, $-\mathrm{Fe}+\mathrm{P}$, or $-\mathrm{Fe}-\mathrm{P}$ for $52 \mathrm{~h}$. Data shown from 12 experiments. In 474 box plots $(F, H)$ center lines show sample medians; box limits indicate the 25th and 475 75th percentiles; whiskers extend 1.5 times the interquartile range from the 25th and 476 75th percentiles. For B, C, F, H, letters above bars or boxes represent statistically different means at $\mathrm{P}<0.05$ (one-way ANOVA with a Duncan post-hoc test). Data points are plotted as open circles. Source data are provided as a Source Data file.

\section{Supplemental Figures}

Figure S1. Photosystem II activity in response to Fe and/or P deficiency in $A$.

thaliana. Seedlings were grown for 7 days in the presence of $\mathrm{Fe}$ and $\mathrm{P}(+\mathrm{Fe}+\mathrm{P})$ and transferred to three different media: $+\mathrm{Fe}+\mathrm{P},-\mathrm{Fe}+\mathrm{P}$, or $-\mathrm{Fe}-\mathrm{P}$ for $15 \mathrm{~h}, 28 \mathrm{~h}, 39 \mathrm{~h}, 52 \mathrm{~h}$, 76h, 100h, 124h, 148h, 172h. Plants were dark-adapted for $30 \mathrm{~min}$ before measuring the kinetics of fluorescence from a leaf. Data shown are from 3 experiments and 13 to 16 plants were measured per experiment. Error bars represent $95 \%$ confidence interval. Source data are provided as a Source Data file.

Figure S2. Transcriptome kinetics of $\boldsymbol{A}$. thaliana in response to $\mathrm{Fe}$ and/or $\mathbf{P}$ deficiency. Volcano plots of individual transcript abundance in wild-type plants (Col0) grown in $-\mathrm{Fe}+\mathrm{P}(\mathrm{A}, \mathrm{C}, \mathrm{E})$ or $-\mathrm{Fe}-\mathrm{P}(\mathrm{B}, \mathrm{D}, \mathrm{F})$ relative to $+\mathrm{Fe}+\mathrm{P}$. Shoot samples were collected from plants grown for $39 \mathrm{~h}(A, B)$, $52 \mathrm{~h}(\mathrm{C}, \mathrm{D})$, or $76 \mathrm{~h}(\mathrm{E}, \mathrm{F})$. x-axis: foldchanges; y-axis: adjusted p-values based on Benjamini-Hochberg correction; Both axes use log scales. Red: log2FoldChange>l2I and -log10P>6; Blue: log2FoldChange $<12$ I and -log10P $>6$; Green: log2FoldChange $>12$ I and $-\log 10 \mathrm{P}<6$;

498 Figure S3. Common and unique genes regulated by Fe and/or P deficiency. A-

499 C) Venn diagrams show the genes that are commonly and specifically increased or 500 decreased in abundance in shoots of $A$. thaliana wild type (Col-0) plants grown in 
$501+\mathrm{Fe}+\mathrm{P}$ for 7 days and transferred to $-\mathrm{Fe}+\mathrm{P}$ or $-\mathrm{Fe}-\mathrm{P}$ for $39 \mathrm{~h}, 52 \mathrm{~h}$, or $76 \mathrm{~h}$ relative to

502 those transferred to $+\mathrm{Fe}+\mathrm{P}$ (fold change $>2, \mathrm{p}<0.05$ ). The Venn diagram was

503 constructed using a web-based tool

504 (http://bioinformatics.psb.ugent.be/webtools/Venn/). p $p=p$-values from

505 hypergeometric testing.

506

Figure S4. Gene Ontology enrichment analysis of genes specifically regulated

508 by $\mathbf{F e}$ and/or $\mathbf{P}$ deficiency. A, C) Heatmaps representing changes in the expression 509 of genes that were specifically decreased in abundance under -Fe-P but not -Fe+P 510 relative to $+\mathrm{Fe}+\mathrm{P}(\mathbf{A})$ and increased in abundance in $-\mathrm{Fe}-\mathrm{P}$ but not in $-\mathrm{Fe}+\mathrm{P}$ relative 511 to $+\mathrm{Fe}+\mathrm{P}$ (C). E) A heatmap representing the expression of genes specifically 512 upregulated by $-\mathrm{Fe}+\mathrm{P}$ but not by $-\mathrm{Fe}-\mathrm{P}$ relative to $+\mathrm{Fe}+\mathrm{P}$. B, D, F) Gene Ontology 513 enrichment for biological processes (GO-BP) in the genes that were specifically 514 decreased by $-\mathrm{Fe}-\mathrm{P}$ relative to $+\mathrm{Fe}+\mathrm{P}(\mathrm{B})$, specifically increased by $-\mathrm{Fe}-\mathrm{P}$ relative to $515+\mathrm{Fe}+\mathrm{P}$ (D), and specifically increased by $-\mathrm{Fe}+\mathrm{P}$ relative to $+\mathrm{Fe}+\mathrm{P}$ (F) using 516 GENEMANIA ${ }^{22}$. Number of genes in each functional category and adjusted p-values 517 for the enrichment are shown. FDR = false discovery rate.

519 Figure S5. Correlation in the expression of the 32 photosynthesis genes specifically downregulated by $-\mathrm{Fe}+\mathrm{P}$ across 727 A. thaliana accessions. A) A

521 heatmap of pairwise correlations (Pearson's correlation coefficient) in the 32 genes 522 across 727 Arabidopsis accessions grown under control conditions. The correlations 523 were calculated using normalized read counts. B) Principal Component (PC) Analysis 524 was performed using the expression of 32 genes in 727 Arabidopsis accessions. X525 and $\mathrm{Y}$-axes show PC 1 and PC 2 that explain $89.5 \%$ and $5.9 \%$ of the total variance, 526 respectively.

528 Figure S6. A close-up view of chromosomes 1 and 4 around bZIP58 and 529 PHT4;4 respectively. A Manhattan plot for genome-wide association mapping using 530 PC 1 of the expression profile of the 32 photosynthesis genes across 727 531 accessions. The five $A$. thaliana chromosomes are depicted by light and dark blue 532 colors. Blue and red horizontal dashed lines correspond to FDR $5 \%$ threshold and 
533 Bonferroni $\alpha=0.05$, respectively. Light blue rectangles indicate the significant SNPs

534 identified in this study. Below the Manhattan plot shows gene models located within a 535 20-kb genomic region surrounding the two QTLs pursued in this study. Source data 536 are provided as a Source Data file.

Figure S7. Effects of $\mathrm{Fe}$ and/or $\mathrm{P}$ availability on chlorophyll content in $\boldsymbol{A}$.

539 thaliana Col-0 and mutants of candidate genes identified using GWAS.

540 Chlorophyll content in Col-0 (CS60000), T-DNA insertion mutant lines in AT1G13570

541 (SALK_139877), AT1G13580 (SALK_150849), AT1G13590 (SALK_063177), 542 AT1G13605 (SALK_087271), AT1G13607 (SALK_130208), $\quad$ AT1G13608 543 (SALK_023173), AT1G13609 (SAIL_1243_E04), AT1G13610 (SAIL_897_D11), 544 At4g00355 (N469134), AT4G00360 (SALK_128714), AT4G00380 (SAIL_842_E09), 545 AT4G03585 (SALK_ 128714), At4g00390 (SAIL_313_F07), and At4g00400 546 (SAIL_633_E10) grown for 7 days in the presence of iron and phosphorus (+Fe+P) 547 and transferred to $+\mathrm{Fe}+\mathrm{P}$, $-\mathrm{Fe}+\mathrm{P}$, or $-\mathrm{Fe}-\mathrm{P}$ for an additional week. Data shown from 3 548 experiments. Error bars represent 95\% confidence interval. Letters a and b indicate 549 significantly different values at $p<0.05$ determined by one-way ANOVA and Tukey's 550 honest significant difference (HSD) tests. Source data are provided as a Source Data 551 file.

\section{Supplemental tables}

554

Table S1. Differentially expressed genes in response to iron and/or

556 phosphorus deficiency in $\boldsymbol{A}$. thaliana. Gene transcript levels were determined in 557 shoots of Col-0 plants grown in control (+Fe+P) condition for 7 days and then 558 transferred to $-\mathrm{Fe}+\mathrm{P},-\mathrm{Fe}-\mathrm{P}$, or $+\mathrm{Fe}+\mathrm{P}$ for $39 \mathrm{~h}, 52 \mathrm{~h}$, or $76 \mathrm{~h}$.

559

560 Table S2. List of primers used in this study.

562 Materials and Methods

563 Plants and growth conditions 
564 Seeds of Arabidopsis thaliana wild type (ecotype Columbia, Col-0, CS60000) and knock-out mutant lines SALK_139877 (AT1G13570), SALK_150849 (AT1G13580), SALK_063177 (AT1G13590), N571881 (AT1G13600), SALK_087271 (AT1G13605), SALK_130208 (AT1G13607), SALK_023173 (AT1G13608), SAIL_1243_E04 (AT1G13609), SAIL_897_D11 (AT1G13610), N469134 (At4g00355), SALK_128714 (AT4G00360), N469134 (AT4G00370), SAIL_842_E09 (AT4G00380), N866595 (At4g00390), SAIL_633_E10 (At4g00400) and SALK_077222 (AT3G02870) were obtained from the Nottingham Arabidopsis Stock Centre (NASC). Homozygous mutant lines were confirmed by PCR using the primers listed in Table S2. bZIP58 complemented lines (bZIP58-CL) were generated by expressing 3896 bp genomic DNA containing bZIP58 in the bzip58 mutant background (NASC, N571881).

575 Complementation of pht4;4 mutant plants (PHT4;4-CL) was obtained by expressing 6450 bp genomic DNA containing PHT4;4 in the pht4;4 mutant background (NASC, N469134). Arabidopsis plants were grown on control (+Fe+P) plates containing 1.249 $\mathrm{mM} \mathrm{KH} \mathrm{KH}_{4} ; 0.25 \mathrm{mM} \mathrm{Ca}\left(\mathrm{NO}_{3}\right)_{2} ; 0.5 \quad \mathrm{mM} \mathrm{KNO}_{3} ; 1 \quad \mathrm{mM} \mathrm{MgSO}_{4} ; 100 \mu \mathrm{M}$ $\mathrm{FeSO}_{4} .7 \mathrm{H}_{2} \mathrm{O} ; 30 \mu \mathrm{M} \mathrm{H} \mathrm{BO}_{3} ; 1 \mu \mathrm{M} \mathrm{ZnCl} 2 ; 10 \mu \mathrm{M} \mathrm{MnCl} ; 1 \mu \mathrm{M} \mathrm{CuCl} ; 0.1 \mu \mathrm{M}$ $\left(\mathrm{NH}_{4}\right)_{6} \mathrm{Mo}_{7} \mathrm{O}_{24} ;$ and $50 \mu \mathrm{M} \mathrm{KCl} ; 0.05 \% 2-(\mathrm{N}$-morpholino)ethanesulfonic acid (MES), without sucrose supplementation, and $0.8 \%$ washed agar. The agar was washed 3

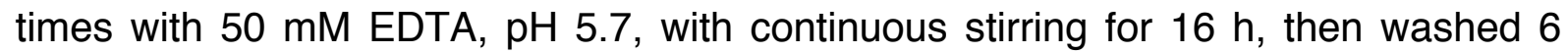
times with Milli-Q de-ionized water for 2 hours to reduce mineral contamination ${ }^{23}$. Pdeficient media contained $12.49 \mu \mathrm{M} \mathrm{KH}_{2} \mathrm{PO}_{4}$ (+Fe-P). Fe-free media was obtained by omitting $\mathrm{FeSO}_{4} .7 \mathrm{H}_{2} \mathrm{O}$ from the growth media $(-\mathrm{Fe}+\mathrm{P})$. $\mathrm{P}$ - and Fe-deficient media contained $12.49 \mu \mathrm{M} \mathrm{KH} \mathrm{PO}_{4}(+\mathrm{Fe}-\mathrm{P})$, and no $\mathrm{FeSO}_{4} \cdot 7 \mathrm{H}_{2} \mathrm{O}(-\mathrm{Fe}-\mathrm{P})$. Seeds were stratified at $4^{\circ} \mathrm{C}$ for 3 days and grown on vertical agar plates in a growth chamber with $22{ }^{\circ} \mathrm{C}, 24 \mathrm{~h}$ of light at $100 \mu \mathrm{mol} \mathrm{m} \mathrm{m}^{-2} \mathrm{~s}^{-1}$ fluorescent illumination. Lemna gibba (duckweed) plants used during this study were obtained from Duckweeds stock center (stock number 29-DWC131) at Rutgers University (USA). Duckweed plants were grown in $1 \mathrm{X}$ Schenk \& Hildebrandt $(\mathrm{SH})$ hydroponic medium containing $0.05 \%$

592 2-(N-morpholino)ethanesulfonic acid (MES) and 1\% sucrose, and pH adjusted to 5.7.

593 For experiments with duckweeds, P-deficient and Fe-deficient media contained 1\% $594 \mathrm{NH}_{4} \mathrm{H}_{2} \mathrm{PO} 4$ and $1 \% \mathrm{FeSO}_{4} 7 \mathrm{H}_{2} \mathrm{O}$, respectively, of $1 \mathrm{X} \mathrm{SH}$ media. Media were changed 595 every 7 days. The growth condition was $22{ }^{\circ} \mathrm{C}$ and $24 \mathrm{~h}$ of light at $80 \mu \mathrm{mol} \mathrm{m}^{-2} \mathrm{~s}^{-1}$. 
596 Rice (Oryza sativa cv Nipponbare) plants were grown hydroponically in 0.25X

597 Yoshida media ${ }^{24}$ under light/dark cycle of $14 / 10 \mathrm{~h}$, and temperature of $28 / 25{ }^{\circ} \mathrm{C}$.

598 Single (-P or -Fe) and combined (-P-Fe) nutrient deficiency stresses were applied to 59910 day-old plants. $\mathrm{NaH}_{2} \mathrm{PO}_{4}(0.33 \mathrm{mM})$ and Fe-NaEDTA $(0.04 \mathrm{mM})$ present in the 600 complete media were omitted in the P-and/or Fe-deficient media.

601

\section{Iron concentration measurement}

603 Arabidopsis seeds were germinated and grown in the control (+Fe+P) media for 7 604 days, and then transferred to $+\mathrm{Fe}+\mathrm{P}$, iron deficient $(-\mathrm{Fe}+\mathrm{P})$, phosphate deficient $605(+\mathrm{Fe}-\mathrm{P})$, or iron and phosphate deficient (-Fe-P) conditions and grown for 7 additional 606 days. Plants were harvested and shoot samples were dried at $70{ }^{\circ} \mathrm{C}$ for 3 days. Total 607 iron was extracted by acid digestion in $1 \mathrm{~N}$ nitric acid using MARSX (CEM) microwave 608 digester. A 1:10 dilution of the digested material was used to quantify total iron with 609 inductively coupled plasma-atomic emission spectrometry (ICP-OES).

\section{Analysis of photosystem II activity}

612 Photosystem II (PSII) activity was defined as the maximum quantum yield of the 613 primary quinone acceptor PSII, which was estimated by the ratio of variable 614 fluorescence $(\mathrm{Fv})$ and maximal fluorescence $(\mathrm{Fm})$ of the chlorophyll, $\mathrm{Fv} / \mathrm{Fm}^{25}$. 615 Arabidopsis wild type (Col-0) seeds were germinated and grown in control $(+\mathrm{Fe}+\mathrm{P})$ 616 for 7 days then transferred to three different media: $+\mathrm{Fe}+\mathrm{P}$, iron deficient $(-\mathrm{Fe}+\mathrm{P})$, 617 and iron and phosphate deficient (-Fe-P) conditions for $0 \mathrm{~h}$ (time of the transfer), 15 618 h, 28 h, 39 h, 52 h, 76 h, 100 h, 124 h, 148 h, and 172 h. Plates containing the 619 seedlings were dark adapted for 30 minutes followed by a very short (160 $\mu \mathrm{s})$ 620 exposure to a blue measuring beam to determine the minimal fluorescence (F0). The 621 intensity of the detecting and the continuous illumination used was of $156 \mu \mathrm{E} \mathrm{m}^{-2} \mathrm{~s}^{-1}$. 622 A saturating light flash $\left(2600 \mu \mathrm{E} \mathrm{m} \mathrm{m}^{-2} \mathrm{~s}^{-1}, 250 \mathrm{~ms}\right)$ was applied to measure the 623 maximum fluorescence $(\mathrm{Fm})$. Kinetics were normalized to the maximum fluorescence 624 (Fm). The maximum quantum yield of Photosystem II (Fv/Fm $=(\mathrm{Fm}-\mathrm{F} 0) / \mathrm{Fm})$ was 625 measured for each growth condition ${ }^{25}$. 
628 Seeds of Arabidopsis genotypes were germinated and grown in control $(+\mathrm{Fe}+\mathrm{P})$ media for 7 days then transferred to three different media: $+\mathrm{Fe}+\mathrm{P}$, iron deficient (-

$630 \mathrm{Fe}+\mathrm{P})$, and iron and phosphate deficient (-Fe-P) conditions. Fresh leaves ( 30mg) 631 were incubated in $2.5 \mathrm{~mL}$ of $80 \%$ acetone overnight in the dark at $4^{\circ} \mathrm{C}$. Total 632 chlorophyll content was measured using a UV-VIS spectrophotometer (Beckman 633 Coulter, DU 530). The absorbance of the supernatant was measured at $645 \mathrm{~nm}$ and $634633 \mathrm{~nm}$. The concentration of total chlorophyll, chlorophyll a, and chlorophyll b were 635 calculated as described previously ${ }^{26}$.

\section{Ascorbic acid content determination}

638 Seeds of Arabidopsis genotypes were germinated and grown in control $(+\mathrm{Fe}+\mathrm{P})$ 639 media and then transferred to $+\mathrm{Fe}+\mathrm{P},-\mathrm{Fe}+\mathrm{P}$, or $-\mathrm{Fe}-\mathrm{P}$ media for $76 \mathrm{~h}$. Ascorbic acid 640 (AsA) content was measured by a colorimetric assay as described previously ${ }^{27}$. 641 Briefly, shoots were collected and homogenized in ice-cold 6\% trichloroacetic acid 642 (TCA) (Sigma Aldrich). In the supernatant, Fe3+ (ferric ion) is reduced by AsA to the 643 Fe2+ (ferrous ion) that, when coupled with 2,2-dipyridyl, forms a complex with a 644 characteristic absorbance at $525 \mathrm{~nm}$. A standard curve was generated using known concentrations of AsA made in 6\% TCA to determine the AsA concentration. Blanks were prepared using only $6 \%$ TCA. AsA concentration was expressed as $\mu \mathrm{mol} \mathrm{g}{ }^{-1}$ fresh weight.

650 Seeds of Arabidopsis genotypes were germinated and grown in control $(+\mathrm{Fe}+\mathrm{P})$ media and then transferred to $+\mathrm{Fe}+\mathrm{P}$, $-\mathrm{Fe}+\mathrm{P}$, or $-\mathrm{Fe}-\mathrm{P}$ media for $76 \mathrm{~h}$. Hydrogen peroxide $\left(\mathrm{H}_{2} \mathrm{O}_{2}\right)$ (Sigma-Aldrich) was quantified as described previously ${ }^{28,29}$. Fresh shoot tissues $(0.2 \mathrm{~g})$ were homogenized with $0.1 \%(\mathrm{w} / \mathrm{v})$ TCA and were centrifuged at $65412,000 \mathrm{~g}$ for $15 \mathrm{~min}$ at $4^{\circ} \mathrm{C}$. $0.5 \mathrm{ml}$ of supernatant was added to $0.5 \mathrm{ml}$ of $10 \mathrm{mM}$ potassium phosphate buffer $(\mathrm{pH} 7.0)$ and $1 \mathrm{ml}$ of $1 \mathrm{M}$ potassium iodide. The absorbance of the reaction mixture was measured at $390 \mathrm{~nm}$. The amount of $\mathrm{H}_{2} \mathrm{O}_{2}$ was calculated using a standard curve prepared from known concentrations of $\mathrm{H}_{2} \mathrm{O}_{2}$ ranging from 0.1 to $1 \mathrm{mM}$. 
661 Arabidopsis wild type (Col-0) plants were grown in control (+Fe+P) media for 7 days 662 and transferred to three different media: control $(+\mathrm{Fe}+\mathrm{P})$, iron deficiency $(-\mathrm{Fe}+\mathrm{P})$, and 663 iron and phosphate deficiency (-Fe-P) conditions. Shoots were collected at 39h, 52h 664 and $76 \mathrm{~h}$ after the transfer. For RNA-seq experiments, three biological replicates were 665 prepared for each time point (39h, 52h and 76h) and each condition (+Fe+P, $-\mathrm{Fe}+\mathrm{P}$ 666 and $-\mathrm{Fe}-\mathrm{P}$ ) for a total of 27 samples. Total RNA was extracted from these samples using RNeasy Plant Mini Kit (QIAGEN) using the RLT buffer supplemented with 2mercaptoethanol, and RNA quality was verified using an Agilent 2100 BioAnalyzer. The mRNAs were subsequently isolated using magnetic KAPA Biosystems oligo-dT beads from KAPA Biosystems (Roche) and then used for library construction using the KAPA Biosystems RNA HyperPrep Kit (Roche). To index the libraries, we used adapters from the KAPA Biosystems Single-Indexed Adapter Set A+B (Roche). Before pooling the libraries, we monitored their quality and concentrations using an Agilent 2100 BioAnalyzer, Qubit dsDNA HS Assay Kit (Thermo Fisher Scientific) and the KAPA Library Quantification Kit (Roche). Pooled libraries were then sequenced using the NextSeq 500 System at the Stanford Functional Genomics Facility (Stanford, CA). Raw reads were demultiplexed and aligned to the TAIR10 genome annotation using HISAT2 $^{30}$ on the Galaxy web platform ${ }^{31}$. Finally, mapped read counts were used to perform normalization and a differential expression analysis on $\mathrm{R}$ using the DESeq2 ${ }^{32}$ and TxDB.Athaliana.BioMart.plantsmart ${ }^{28}$ (Bioconductor) packages. In DESeq2, p-values from the Wald test were corrected for multiple hypothesis testing using the Benjamini and Hochberg method. A transcript was considered differentially expressed if the adjusted $p$-value $<0.05$. Volcano plots were generated using the EnhancedVolcano package (version 1.6.0) (Bioconductor) with a default cut-off of log2(Fold Change) $>|2|$ and adjusted $p$ value $<10 e^{-6}$. DEGs having a $p$-value of 0 were converted to $10^{-1} \times$ lowest non-zero $p$-value.

\section{Real-time quantitative reverse-transcription PCR}

689 Seeds of Arabidopsis wild type (Col-0), bzip58, and pht4;4 mutant plants were 690 germinated and grown for 7 days in control $(+\mathrm{Fe}+\mathrm{P})$ media, and then transferred to 
$691+\mathrm{Fe}+\mathrm{P}, \mathrm{Fe}+\mathrm{P}$, or $-\mathrm{Fe}-\mathrm{P}$. Shoot tissues were collected at $76 \mathrm{~h}$ after the transfer, and 692 then used for total RNA extraction as described $\mathrm{in}^{33}$. Each experiment was conducted 693 with 16 plants and 4-6 plants were pooled for RNA extraction, resulting in 3-4 694 biological replicates. Two $\mu \mathrm{g}$ of the total RNA was used for reverse transcription 695 (Promega) to synthesize cDNA using oligo(dT) primer (Promega). Real-time 696 quantitative reverse-transcription PCR (qRT-PCR) was performed as described $\mathrm{in}^{33}$ 697 using 384-well plates with a LightCycler 480 Real-Time PCR System (Roche 698 diagnostics). The Ubiquitin 10 mRNA (UBQ10: At4g05320) was used as control to 699 calculate the relative mRNA level of each gene. The primers used in this study are 700 listed in Table S2.

703 Gene expression data of the 32 genes that were specifically downregulated by $-\mathrm{Fe}+\mathrm{P}$ 704 but not by $-\mathrm{Fe}-\mathrm{P}$ relative to $+\mathrm{Fe}+\mathrm{P}$ were downloaded from leaf expression data of 727 705 Arabidopsis accessions ${ }^{15}$. Normalized RNA-seq read counts of these genes were 706 used to perform Principal Component Analysis, and contributions of the accessions 707 to PC1 that explained $89.5 \%$ of the expression variance of the 32 genes were used to 708 run genome-wide association (GWA) analysis. GWA mapping was performed using 7091001 genomes SNP data ${ }^{34}$ as implemented in the web application GWAPP ${ }^{35}$. 710 Bonferroni correction $(\alpha=0.05)$ and false-discovery rate (FDR) at $5 \%{ }^{36}$ were 711 implemented to account for multiple hypothesis tests.

\section{Statistical analysis}

713 Box plots were generated using a web based application "BoxPlotR"37. Statistical 714 analyses of the data were performed using analysis of variance (ANOVA). One-way 715 ANOVA with a Duncan post-hoc test, and two-way analysis of variance (ANOVA) and 716 Tukey's honest significant difference (HSD) test were used to compare mean values. 717 For all the statistical analyses, the difference was considered statistically significant 718 when the test yielded a $p$-value $<0.05$. 
720 The authors thank the members of Rhee lab; Benoit Lacombe and HONUDE team

721 (INRAe) for their comments on the manuscript and helpful discussions. We thank the 722 ICP-MS/TIMS Facility within Stanford University for assistance with the ICP-MS 723 measurements, and the Stanford Functional Genomics Facility for assistance with

724 RNA sequencing (Stanford, CA). The GWAS analysis was made possible by data 725 generated by Kawakatsu et al. ${ }^{15}$.

\section{Funding}

728 This work was funded in part by the "Institut National de la Recherche Agronomique 729 - Montpellier - France" INRA, the AgreeenSkills Plus, and Michigan State University 730 (USA) to H.R. as well as by the Carnegie Institution for Science, Brigitte Berthelemot, 731 National Science Foundation (IOS-1546838, IOS-1026003), and the U.S. Department 732 of Energy, Office of Science, Office of Biological and Environmental Research, 733 Genomic Science Program grant nos. DE-SC0018277, DE-SC0008769, and DE734 SC0020366 to S.Y.R. The funders had no role in study design, data collection and analysis, decision to publish, or preparation of the manuscript.

\section{Competing interests}

738 No competing interests declared.

\section{Contributions}

741 S.Y.R. and H.R. conceived the project. Experiments were designed by S.Y.R., H.R., 742 H.N., and Z.S. and mainly carried out by H.N. S.C. performed and analyzed 743 experiments related to photosystem II activity. bZIP58-GFP localization, ascorbic acid 744 quantification and hydrogen peroxide assays were conducted by H.C. and N.B. RNA745 seq data were generated and analyzed by Y.D. Gene Ontology analysis was 746 performed K.Z. Z.S. performed the genome-wide association mapping. H.R. 747 performed the qRT-PCR analyses, generated plasmid constructs, the homozygote 748 mutants, and the complemented mutant lines. S.Y.R., H.R. and Z.S. wrote the paper 749 with input from all authors.

\section{Data availability}


752 Data supporting the findings of this work are available within the paper and its 753 Supplementary Information and Source Data files. The datasets and plant materials 754 generated and analyzed during the current study are available from the 755 corresponding author H.R. upon request. Transcriptome data were deposited in 756 NCBI's Gene Expression Omnibus (GEO) under a project number GSE163190. 
Figure 1

A
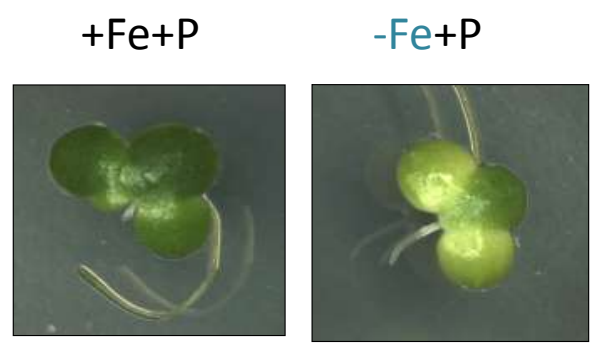

C
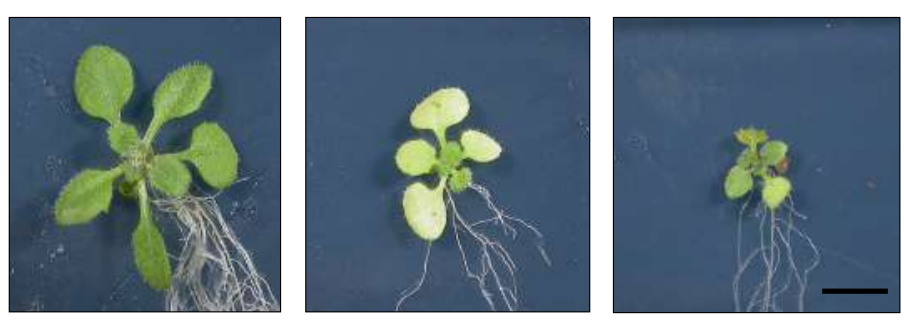

E
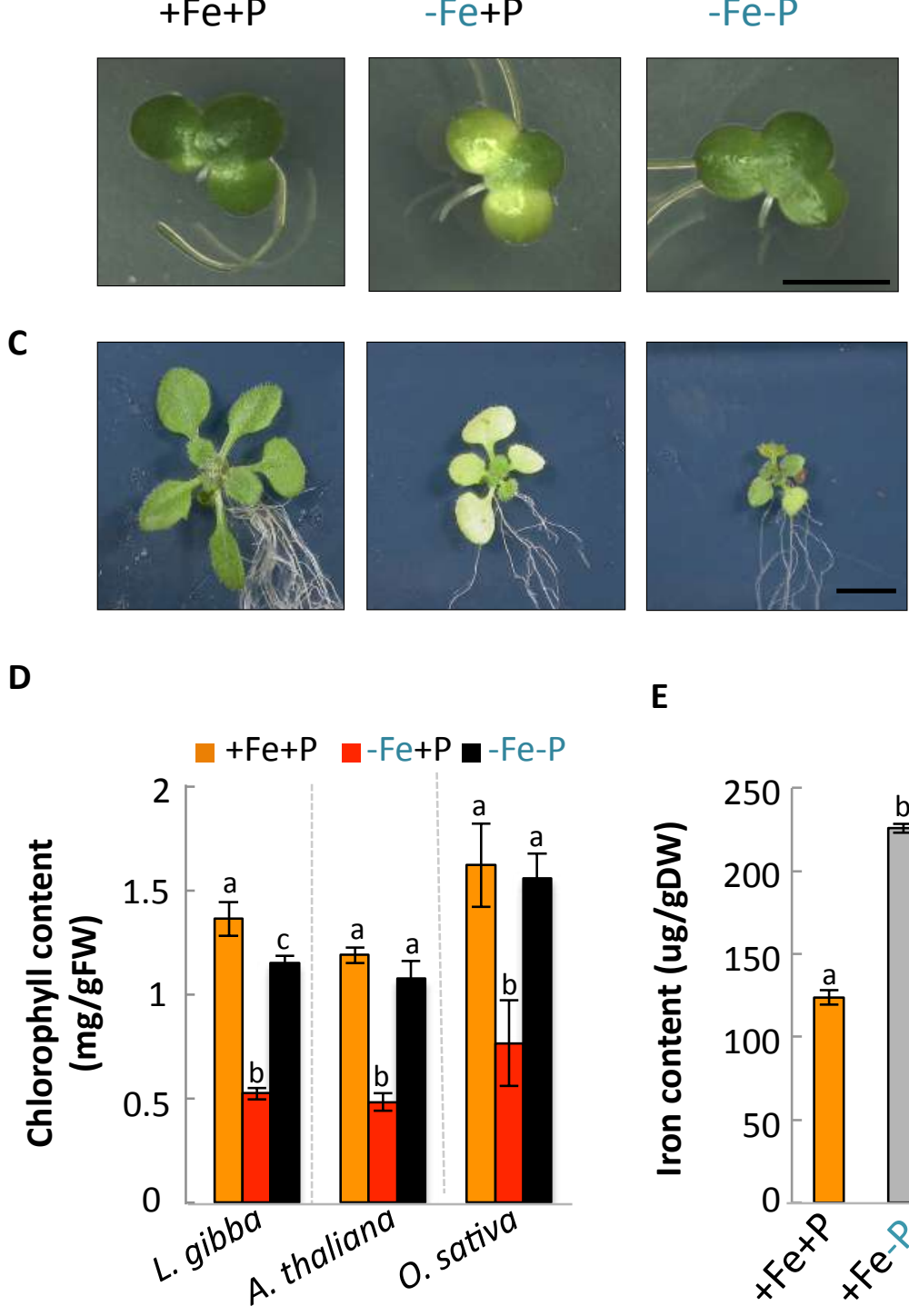

D
B
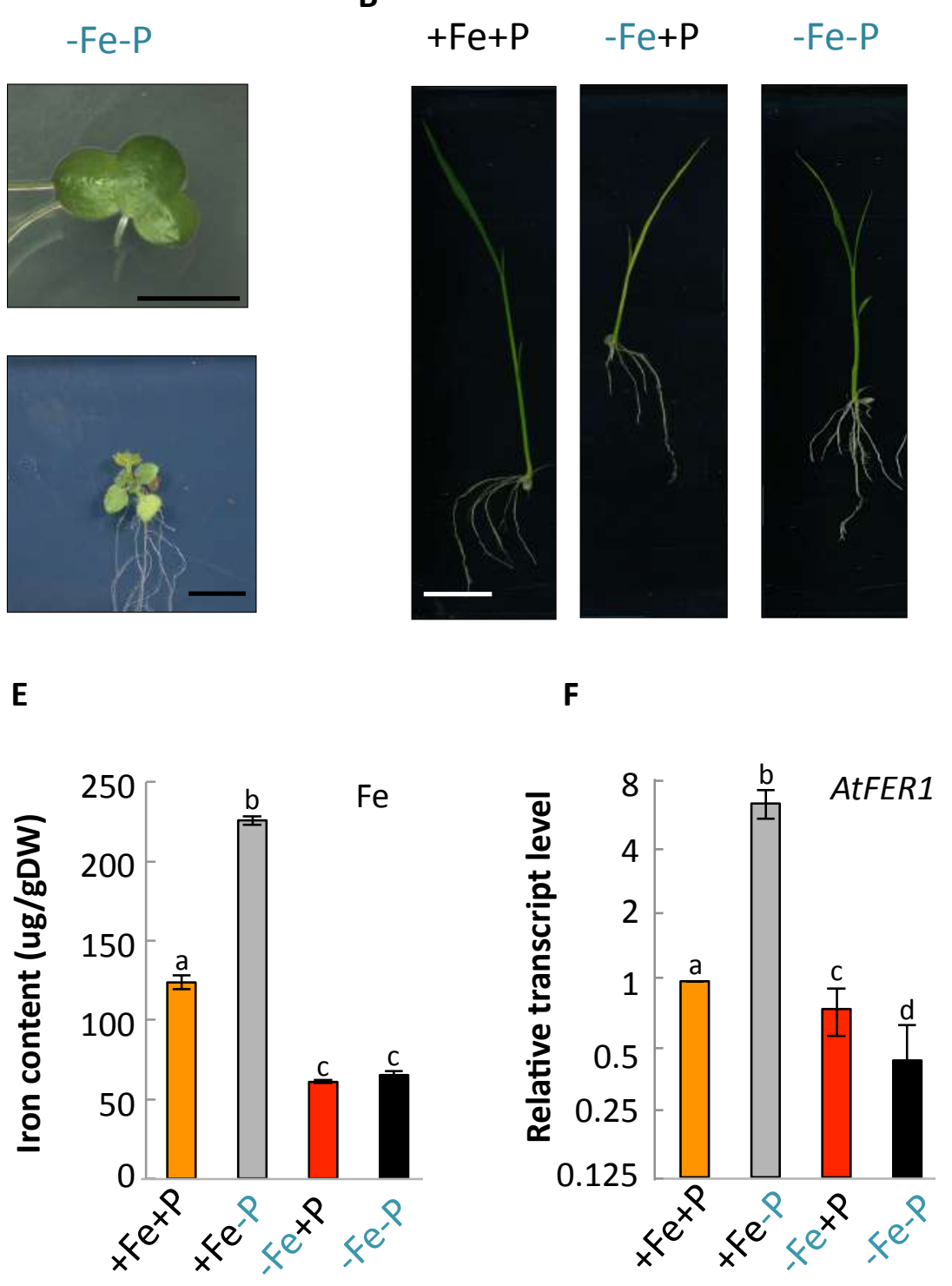


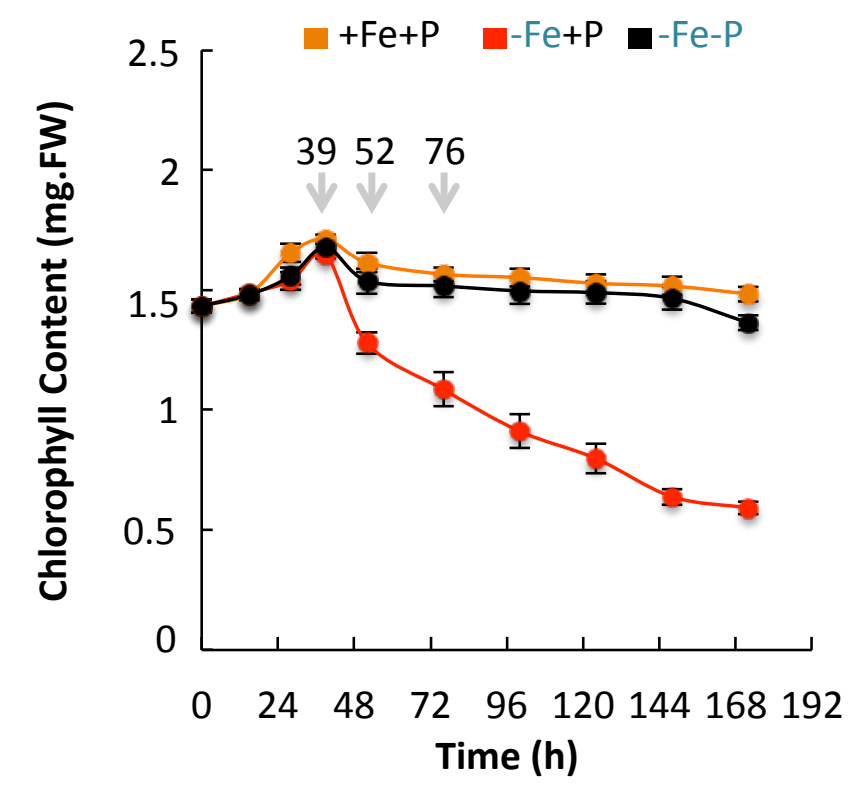

C

\section{$\underline{\text { Treatments } \quad \text { Harvesting }}$}

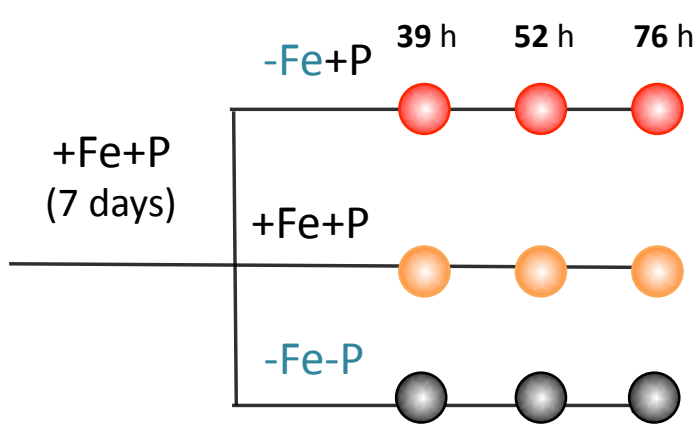

E
D

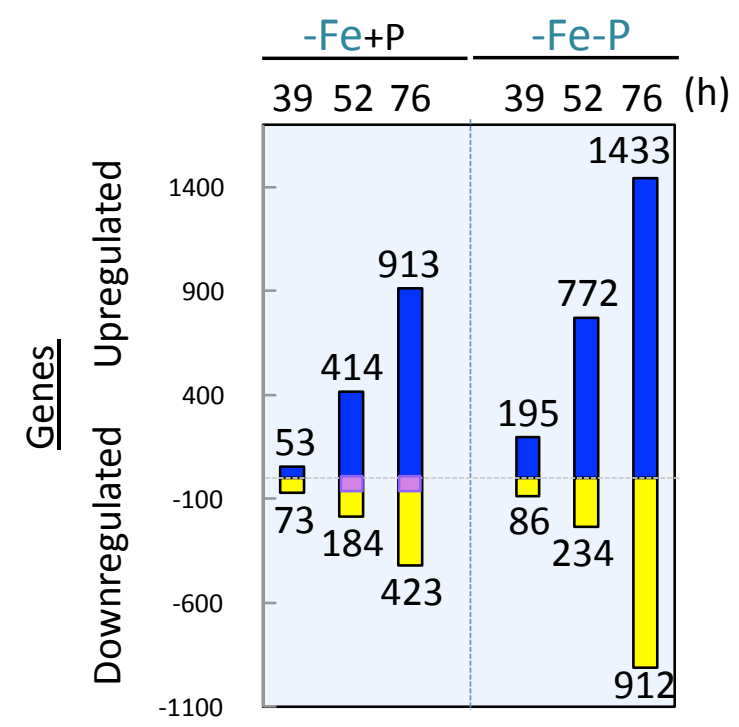

$\mathbf{F}$

\section{Gene function}

Plastid thylakoid membrane Photosynthetic membrane Thylakoid membrane

Chloroplast thylakoid membrane

Photosystem

Plastoglobule

Photosynthesis

Chlorophyll binding

Photosystem I

Tetrapyrrole binding

Light-harvesting complex

Photosystem II

Photosynthesis, light reaction

Response to red light

Chloroplast photosystem II

Plastid thylakoid lumen

Chloroplast thylakoid lumen

Thylakoid lumen

Precursor metabolites and energy

Response to far red light

\section{Number of genes per FDR gene function}

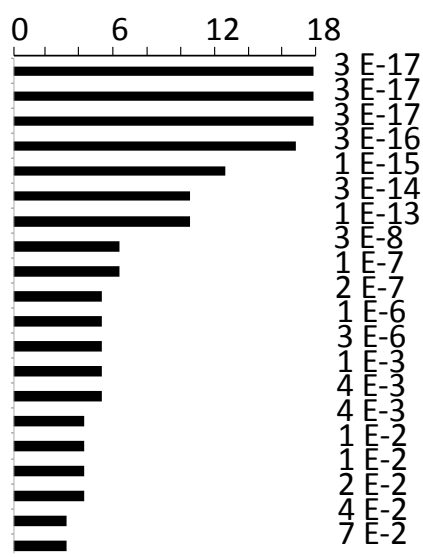






B
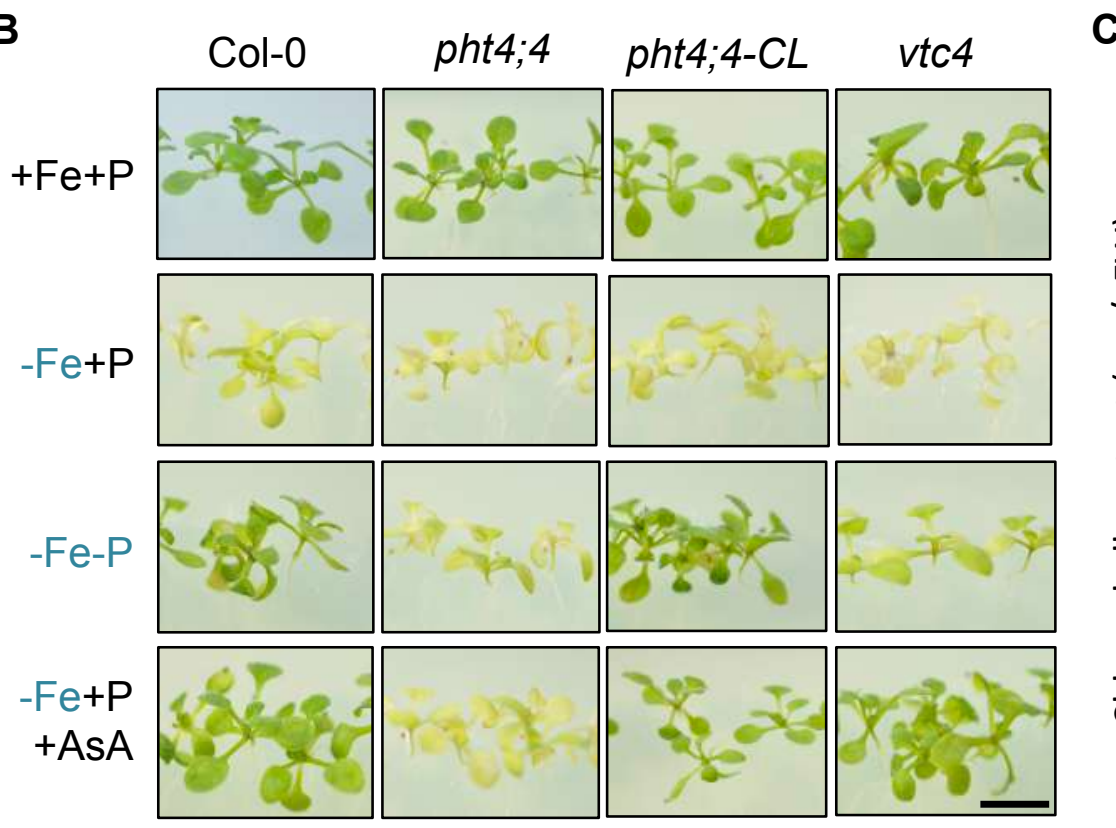

$+\mathrm{Fe}+\mathrm{P} \square-\mathrm{Fe}+\mathrm{P} \square-\mathrm{Fe}-\mathrm{P} \square-\mathrm{Fe}+\mathrm{P}+\mathrm{AsA}$

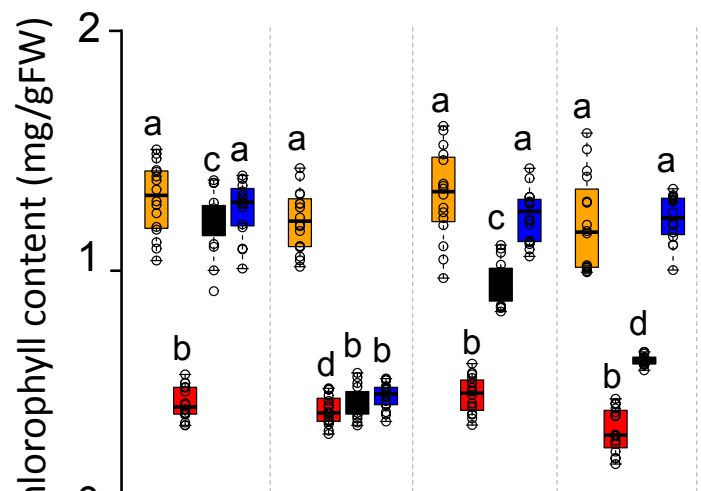

Col-0 pht4;4 pht4;4-CL vtc4
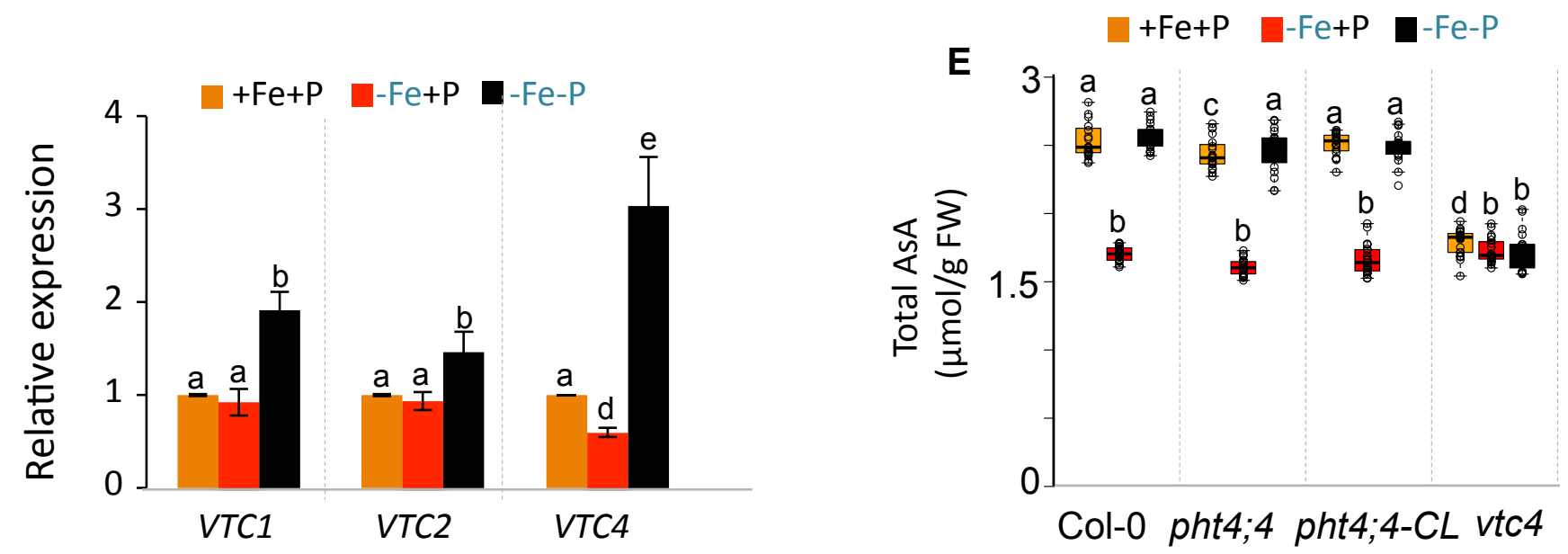


\section{Figure 4}

A

\section{Genes Col-0 pht4;4 bzip58}

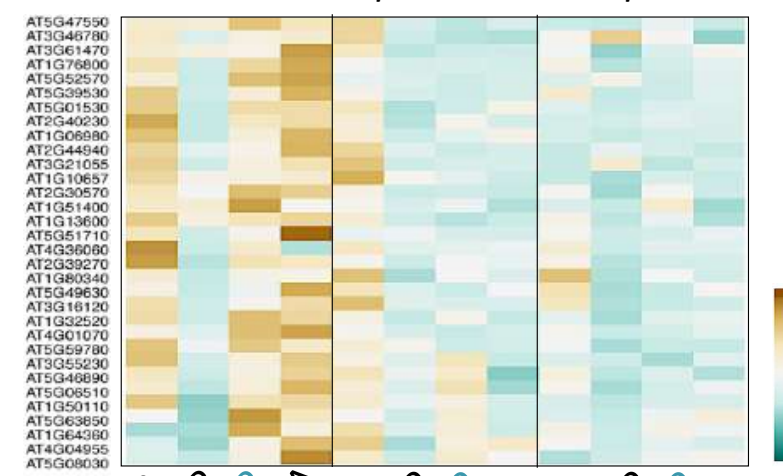

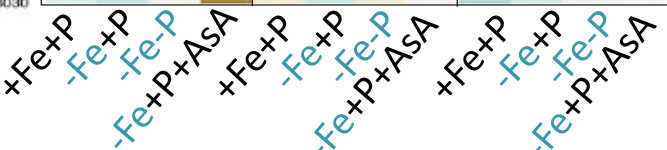

D

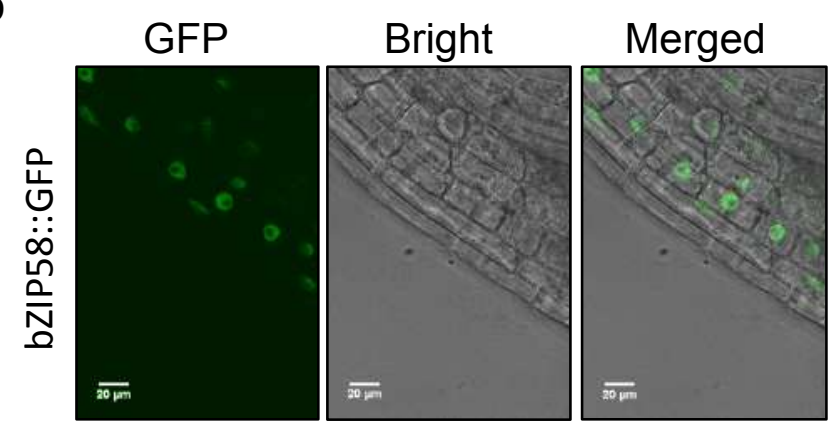

$\mathbf{F}$

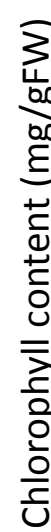

0

$$
\text { Col-0 bzip58 bzip58-CL }
$$



B

bZIP58

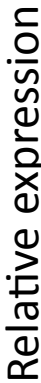

0

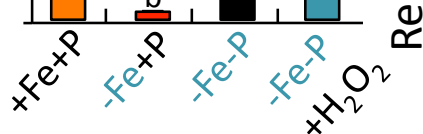

C $\quad \underline{\text { TTC4 }}$

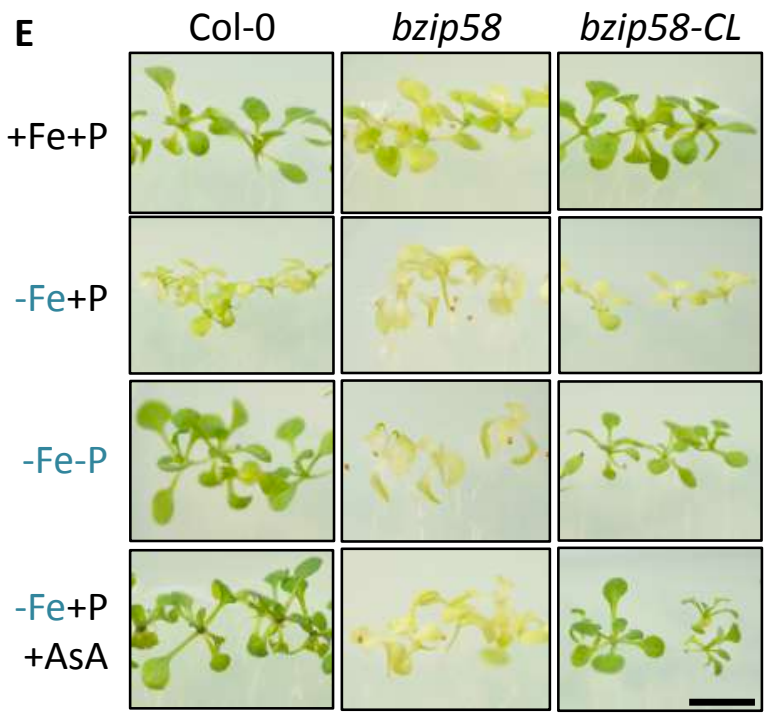

H

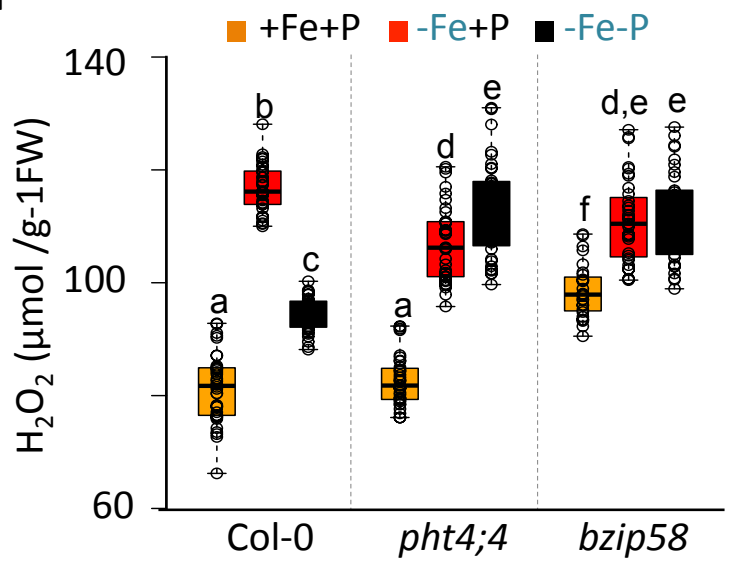

G

$+\mathrm{Fe}+\mathrm{P}$

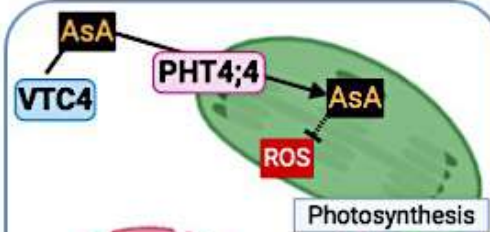

bZIP58

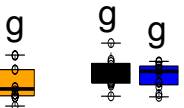

$\stackrel{d}{d}+$

$-\mathrm{Fe}+\mathrm{P}$

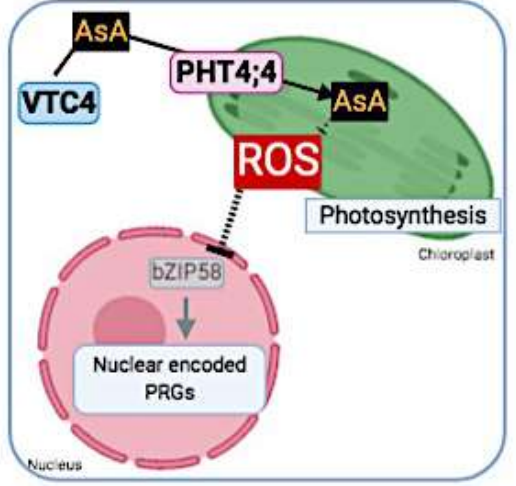

-Fe-P

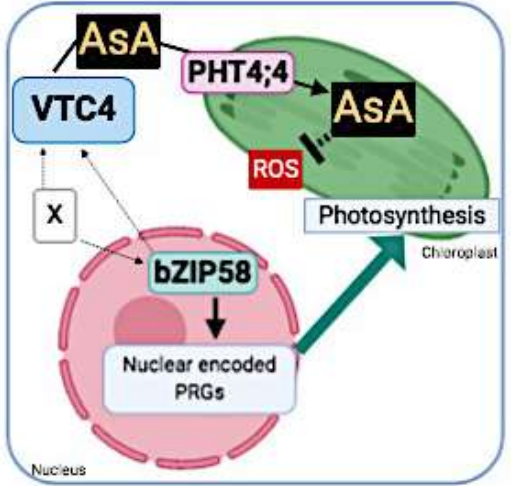


A

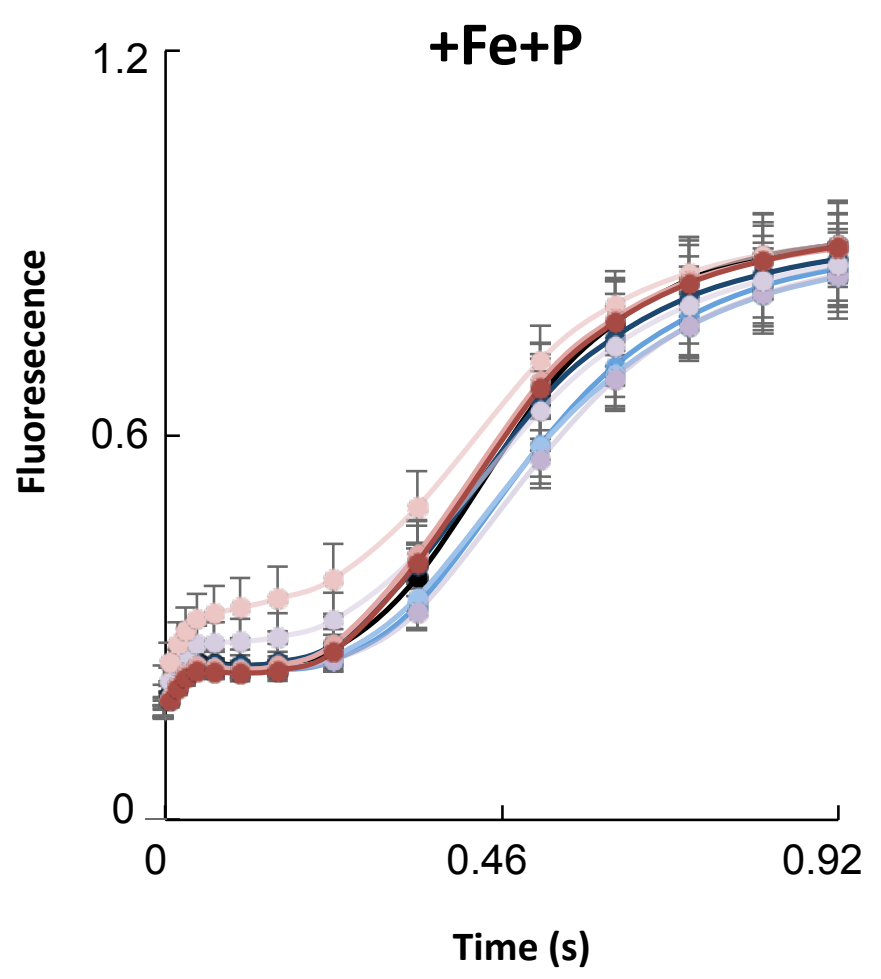

C

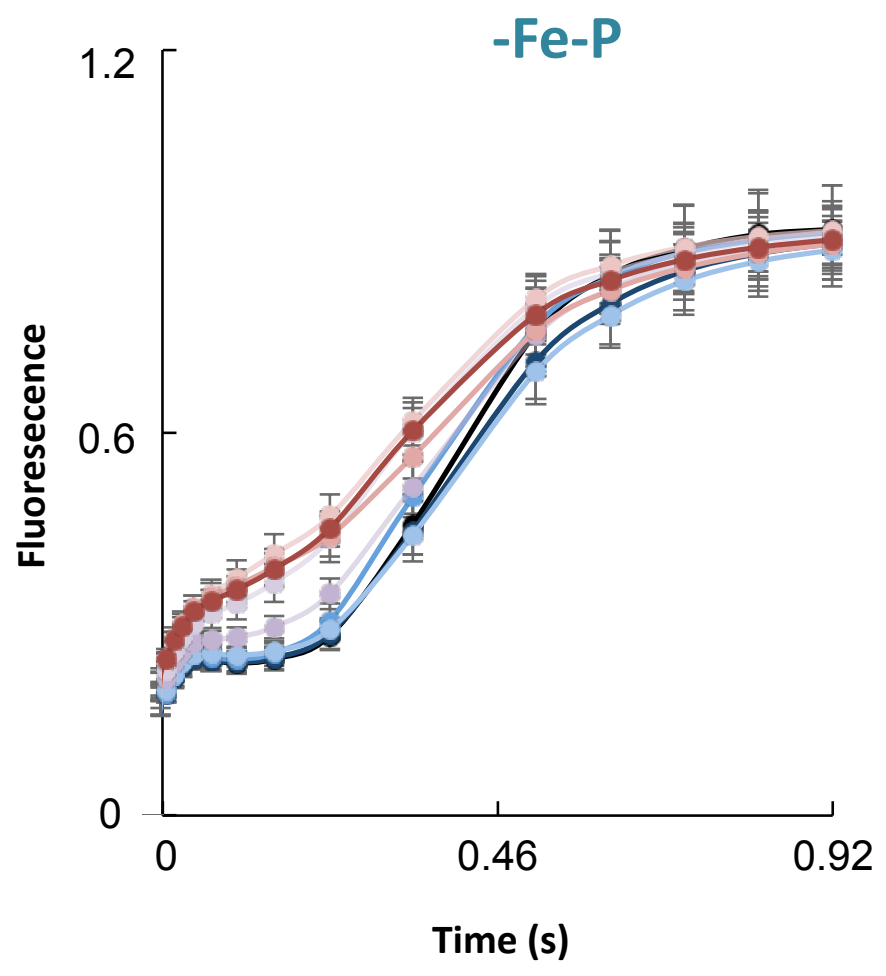

Time (s)
B

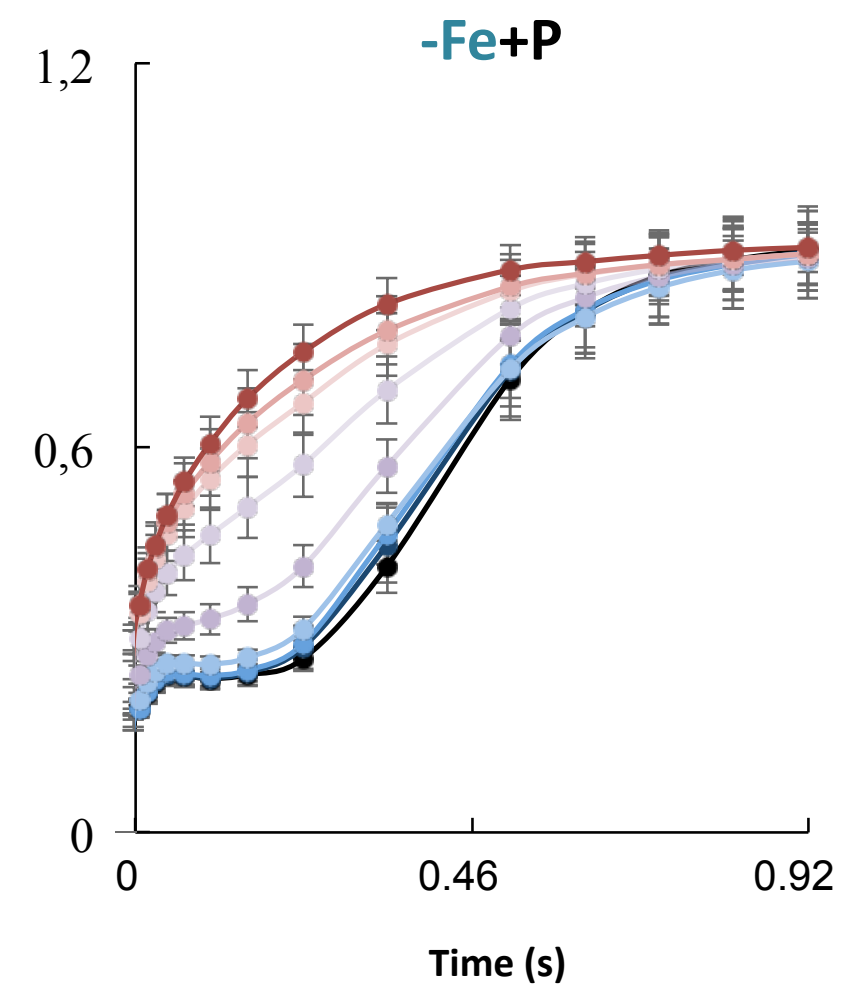

$\rightarrow 15 \mathrm{~h}$

$\rightarrow 28 \mathrm{~h}$

$\rightarrow-39 \mathrm{~h}$

$-52 \mathrm{~h}$

$-76 \mathrm{~h}$

- $100 \mathrm{~h}$

$-124 \mathrm{~h}$

$-148 \mathrm{~h}$

$\rightarrow 172 \mathrm{~h}$ 
Supplemental Figure $2 \quad O N S \quad \log _{2} F C \bigcirc p$-value $\bigcirc$-value and $\log _{2} F C$

A

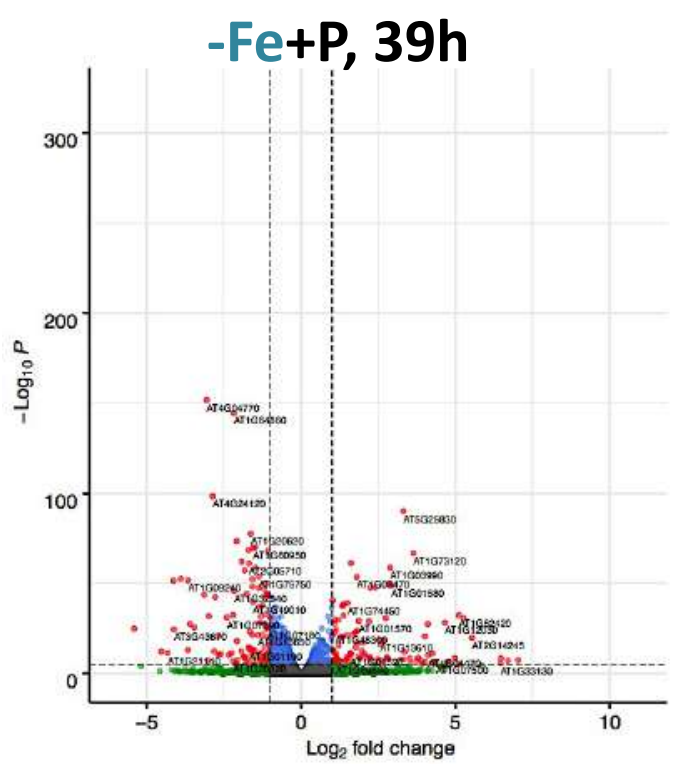

C

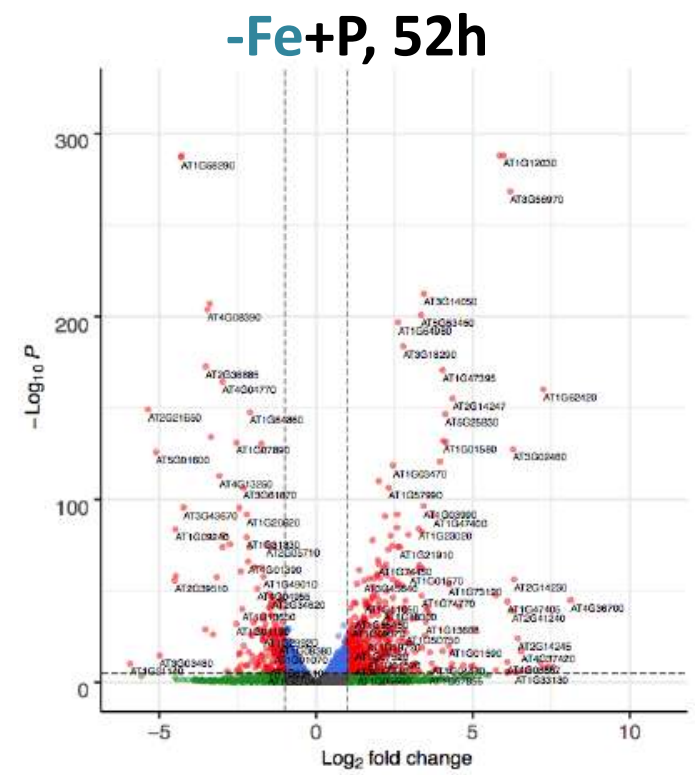

E

$$
\text { -Fe+P, 76h }
$$

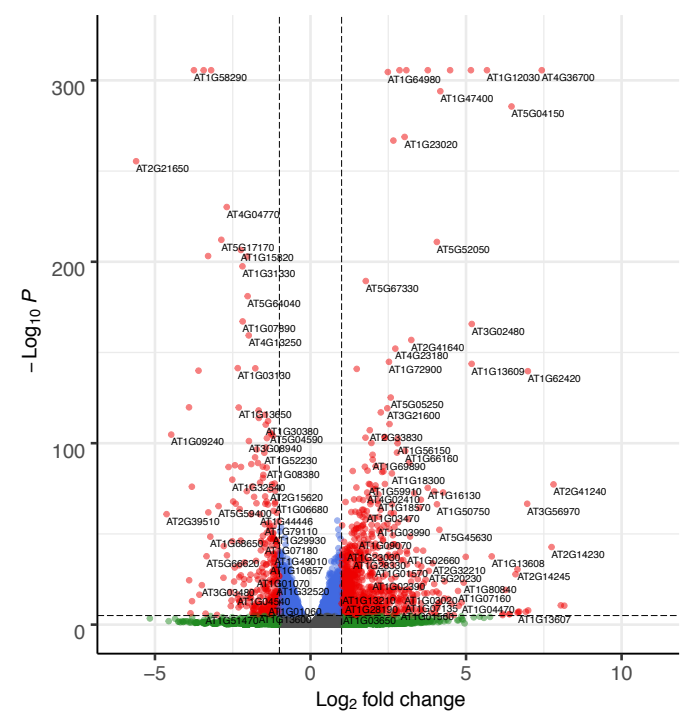

B

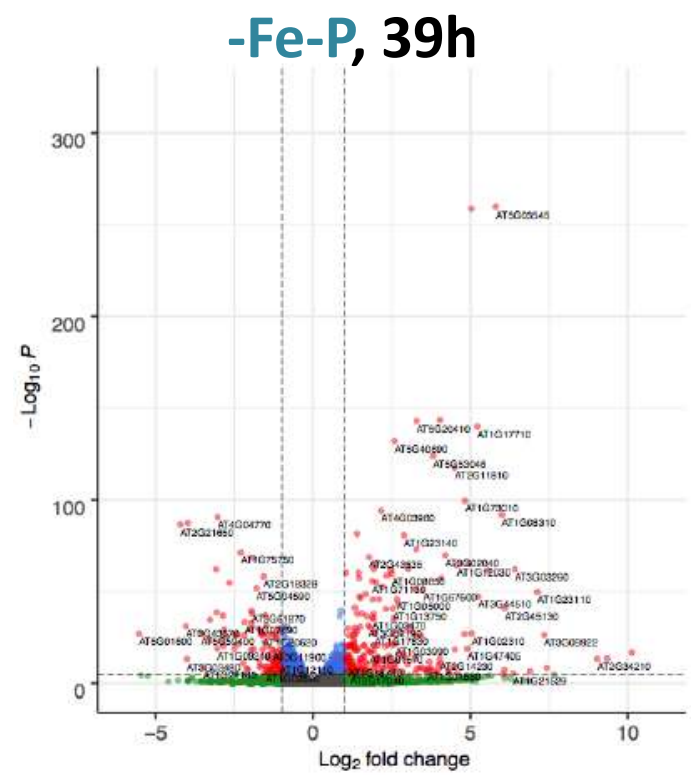

D

$$
\text { -Fe-P , 52h }
$$

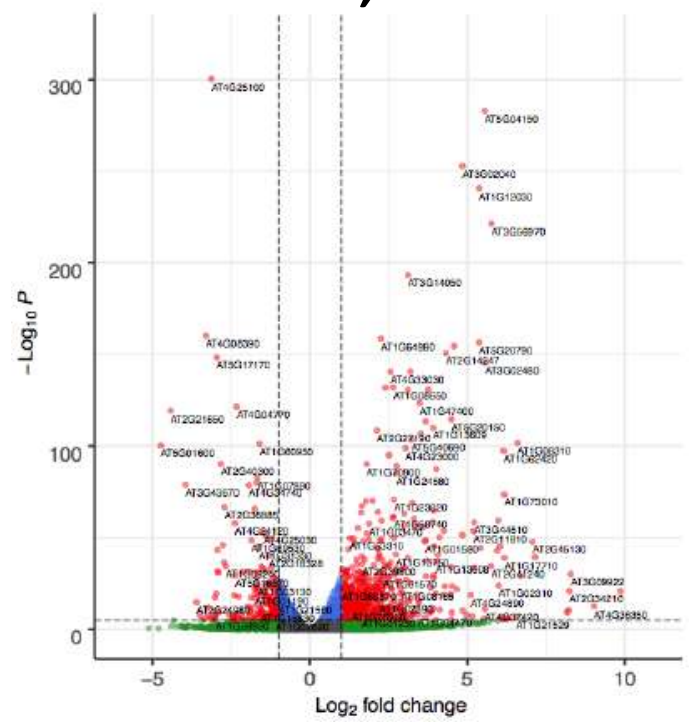

$\mathbf{F}$

-Fe-P, 76h




A

$$
\begin{aligned}
& \underline{39 h} \\
& \text {-Fe+P -Fe-P } \\
& p=3.23 E-75 \\
& 13 \div 40 \quad 155 \\
& \begin{array}{llll}
\text { Up } & (6.25 \%) & (19.25 \%) & (74.5 \%)
\end{array} \\
& 14 \div 59 \quad 27 \\
& \text { Down }(14 \%)(59 \%) \quad(27 \%) \\
& p=1.41-143
\end{aligned}
$$

B

$$
\begin{aligned}
& \underline{52 h} \\
& -F e+P \quad-F e-P \\
& p=1.22 E-426 \\
& \text { Up } \begin{array}{cccc}
93 & 321 & 451 \\
(10.8 \% & (37.1 \%) & (52.1 \%)
\end{array} \\
& 82-102 \quad 132 \\
& \text { Down (25.94\%) (32.28\%) (41.78\%) } \\
& p=5.90 E-166 \\
& \text { 76h } \\
& \text {-Fe+P -Fe-P } \\
& p=1.93 E-435 \\
& \text { Up } \begin{array}{ccl}
390 & 523 & 910 \\
(21.4 \%) & (28.68 \%) & (49.92 \%)
\end{array} \\
& \begin{array}{lll}
81 & 153 & 759
\end{array} \\
& \text { Down (8.16\%) (15.40\%) (76.44\%) } \\
& p=5.38 E-164
\end{aligned}
$$

C 
A

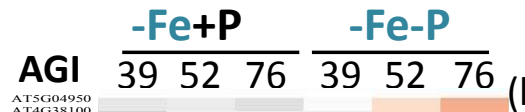

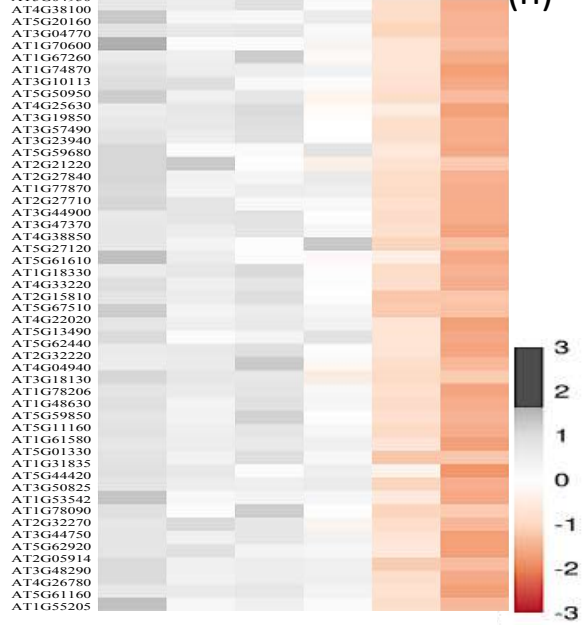

C

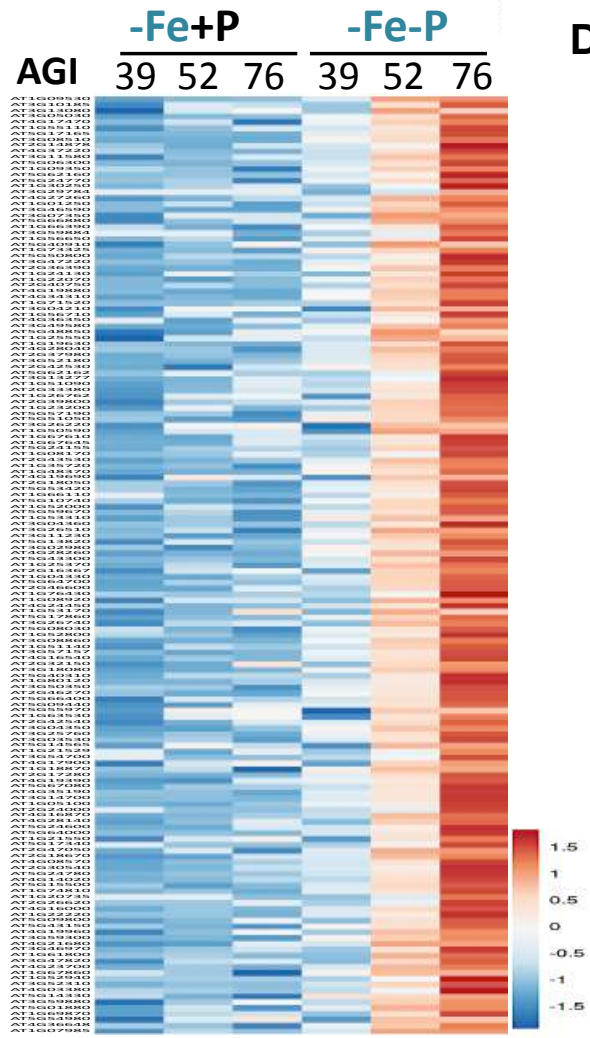

E

AGI $\frac{-F e+P}{395276} \frac{-F e-P}{395276}$

AT1G23030
AT1G05680

D

\section{Gene function}

Phosphoric diester hydrolase activity Phosphoric ester hydrolase activity Response to water Response to water deprivation Response to desiccation Phospholipase $\mathrm{C}$ activity

Monovalent inorganic cation transport

Metal ion transmembrane transporter activity

Glycerophosphodiester phosphodiesterase activity

Cation transport
Number of genes per gene function

FDR

\begin{tabular}{lllll}
0 & 5 & 10 & 15 & 20 \\
\hline
\end{tabular}

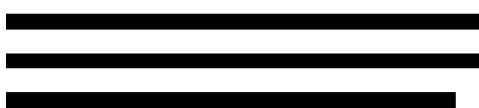

$8 \mathrm{E}-21$

$8 \mathrm{E}-21$

$3 \mathrm{E}-20$

$5 \mathrm{E}-11$

$1 \mathrm{E}-11$

$1 \mathrm{E} 10$

$4 \mathrm{E}-8$

$5 \mathrm{E} 8$

$2 \mathrm{E}-7$

$4 \mathrm{E}-7$

$2 \mathrm{E}-2$
Number of genes per gene function

FDR

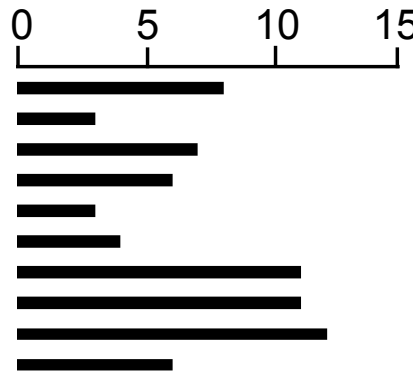

$2 \mathrm{E}-3$

$2 \mathrm{E}-3$

$2 \mathrm{E}-3$

$2 \mathrm{E}-3$

$1 \mathrm{E}-2$

$1 \mathrm{E}-1$

$1 \mathrm{E}-1$

$2 \mathrm{E}-1$

$2 \mathrm{E}-1$

$2 \mathrm{E}-1$
$\mathbf{F}$ Gene function

Cellular respiration

Energy derivation by oxidation of organic compounds

Oxidation-reduction process

Generation of precursor metabolites and energy
Number of genes per gene function

FDR

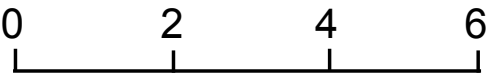

$3 \mathrm{E}-5$

$3 \mathrm{E}-5$

$4 \mathrm{E}-3$

$4 \mathrm{E}-3$ 
Supplemental Figure 5

A

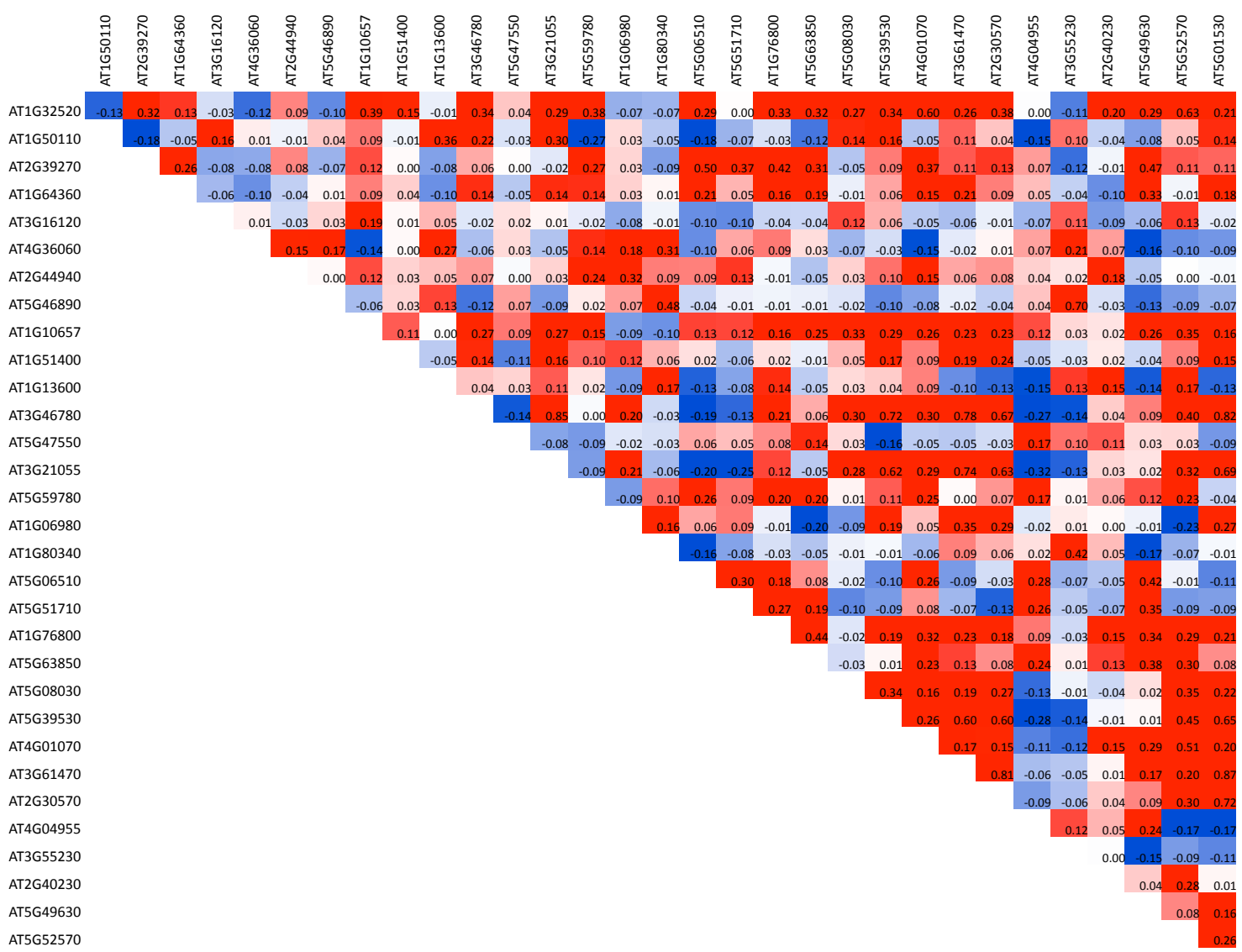

B

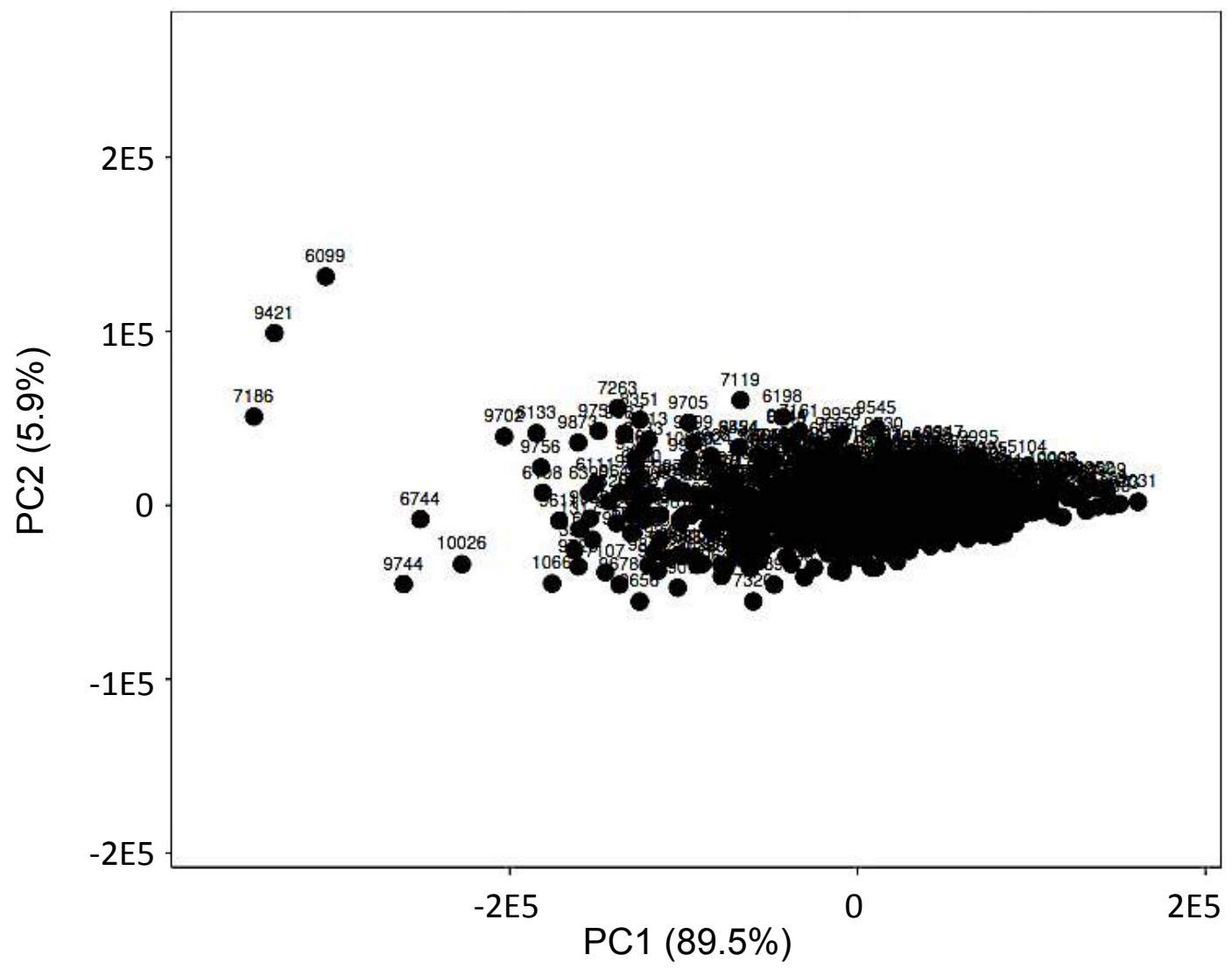




\section{Supplemental Figure 6}

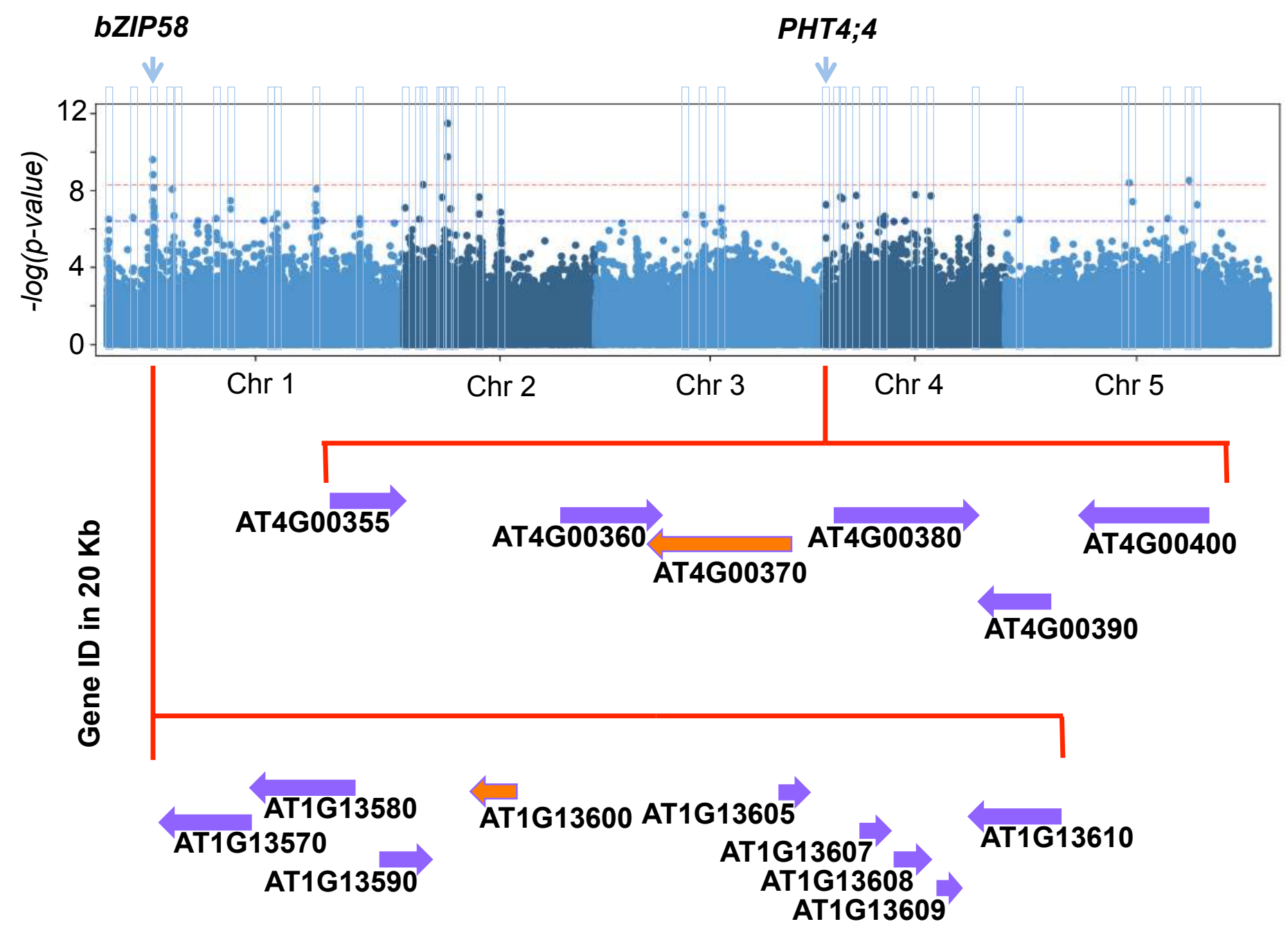


$\square+\mathrm{Fe}+\mathrm{P} \quad \square-\mathrm{Fe}+\mathrm{P} \quad \square$-Fe-P

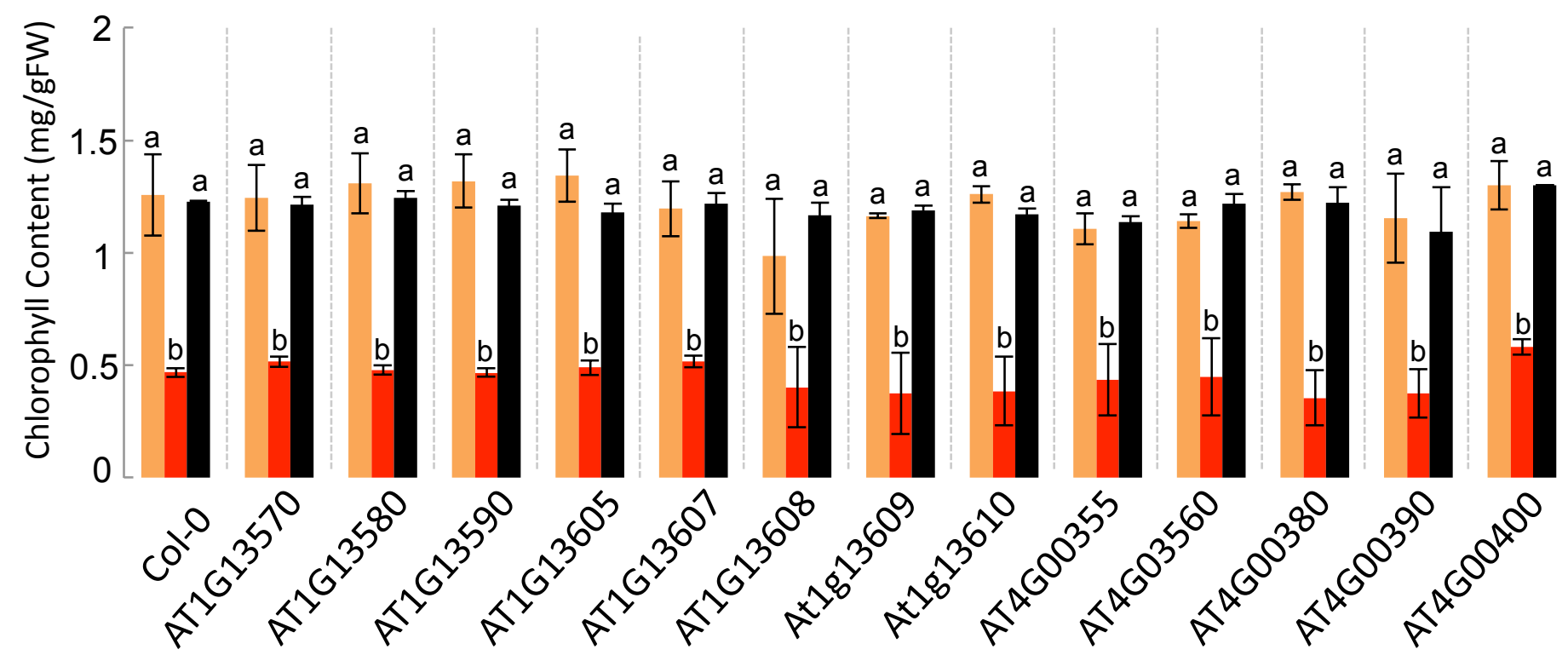

